\title{
THERMOPHYSICAL PROPERTIES OF SATURATED LIGHT AND HEAVY WATER FOR ADVANCED NEUTRON SOURCE APPLICATIONS
}

\author{
Allen Crabtree \\ Moshe Siman-Tov
}

May 1993

Prepared by

OAK RIDGE NATIONAL LABORATORY

Oak Ridge, Tennessee 37831

managed by

MARTIN MARIETTA ENERGY SYSTEMS, INC.

for the

U.S. DEPARTMENT OF ENERGY

under contract DE-AC05-84OR21400 
CONTENTS

Page

LIST OF FGURES $\ldots \ldots \ldots \ldots \ldots \ldots \ldots \ldots \ldots \ldots \ldots \ldots \ldots \ldots \ldots \ldots$

LIST OF TABLES $\ldots \ldots \ldots \ldots \ldots \ldots \ldots \ldots \ldots \ldots \ldots \ldots \ldots \ldots \ldots \ldots \ldots$

NOMENCLATURE $\ldots \ldots \ldots \ldots \ldots \ldots \ldots \ldots \ldots \ldots \ldots \ldots \ldots \ldots \ldots \ldots \ldots$ vii

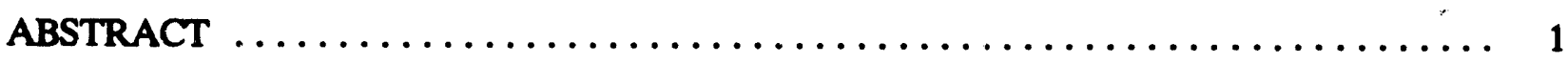

1. INTRODUCTION $\ldots \ldots \ldots \ldots \ldots \ldots \ldots \ldots \ldots \ldots \ldots \ldots \ldots \ldots \ldots \ldots \ldots$

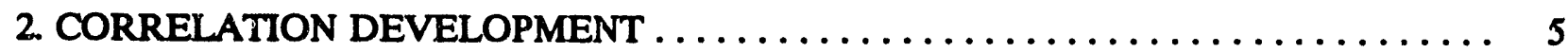

2.1 LIGHT WATER CORRELATION DEVELOPMENT $\ldots \ldots \ldots \ldots \ldots \ldots \ldots \ldots \ldots$.

2.2 HEAVY WATER CORRELATION DEVELOPMENT $\ldots \ldots \ldots \ldots \ldots \ldots \ldots \ldots .6$

3. ANALYTICAL CORRELATIONS $\ldots \ldots \ldots \ldots \ldots \ldots \ldots \ldots \ldots \ldots \ldots$

3.1 PHYSICAL PROPERTY CORRELATIONS FOR SATURATED

LIGHT WATER $\ldots \ldots \ldots \ldots \ldots \ldots \ldots \ldots \ldots \ldots \ldots \ldots \ldots \ldots \ldots \ldots \ldots$

3.2 PHYSICAL PROPERTY CORRELATIONS FOR SATURATED

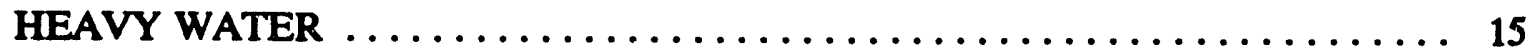

4. PHYSICAL PROPERTY COMPUTER CODES $\ldots \ldots \ldots \ldots \ldots \ldots \ldots \ldots \ldots \ldots \ldots$

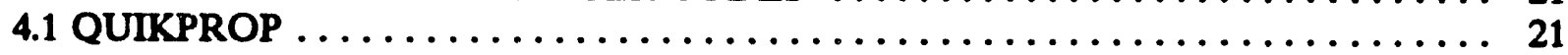

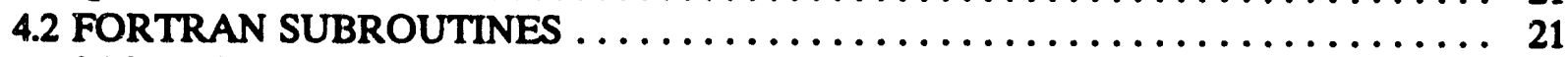

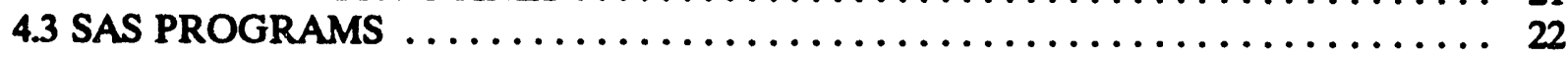

5. PHYSICAL PROPERTY TABLES AND GRAPHS $\ldots \ldots \ldots \ldots \ldots \ldots \ldots \ldots \ldots$

6. RECOMMENDATIONS $\ldots \ldots \ldots \ldots \ldots \ldots \ldots \ldots \ldots \ldots \ldots \ldots \ldots \ldots \ldots$

ACKNOWLEDGMENTS $\ldots \ldots \ldots \ldots \ldots \ldots \ldots \ldots \ldots \ldots \ldots \ldots \ldots \ldots$

REFERENCES $\ldots \ldots \ldots \ldots \ldots \ldots \ldots \ldots \ldots \ldots \ldots \ldots \ldots \ldots \ldots \ldots \ldots \ldots \ldots \ldots$

iii 


\section{LIST OF FIGURES}

\section{Page}

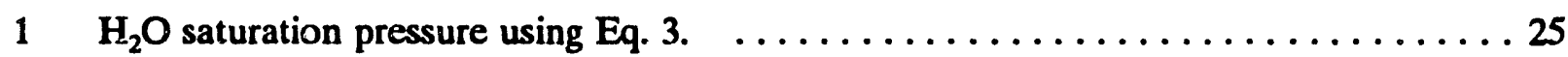

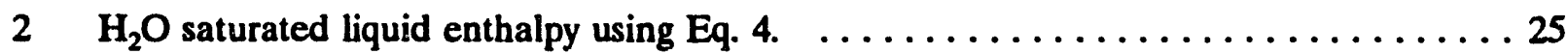

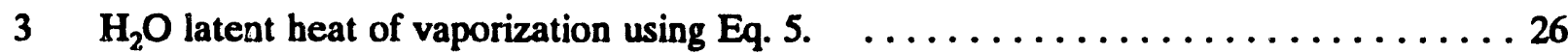

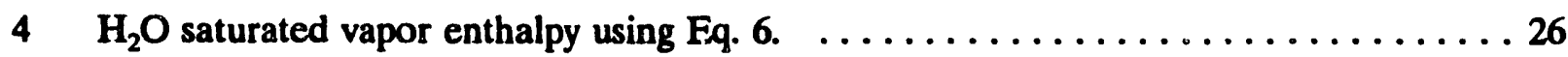

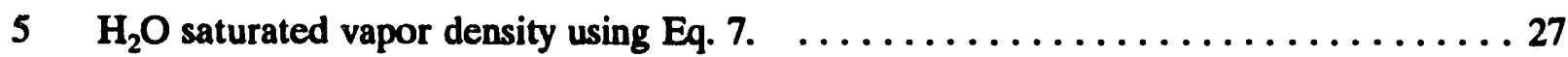

$6 \mathrm{H}_{2} \mathrm{O}$ saturated liquid density using Eq. 8. $\ldots \ldots \ldots \ldots \ldots \ldots \ldots \ldots \ldots \ldots \ldots$

$7 \quad \mathrm{H}_{2} \mathrm{O}$ saturated liquid thermal conductivity using Eq. 9. $\ldots \ldots \ldots \ldots \ldots \ldots \ldots \ldots$

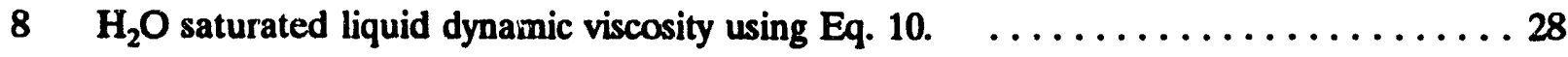

$9 \mathrm{H}_{2} \mathrm{O}$ saturated liquid specific heat using Eq. 11. $\ldots \ldots \ldots \ldots \ldots \ldots \ldots \ldots \ldots$

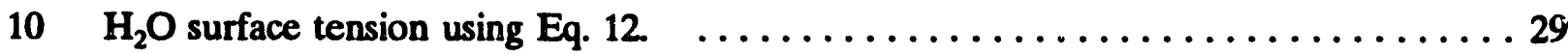

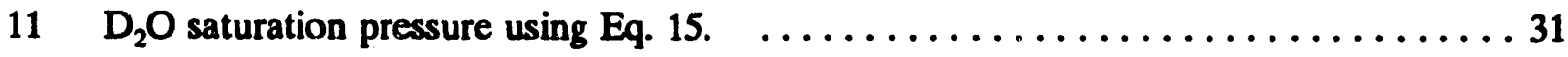

$12 \mathrm{D}_{2} \mathrm{O}$ saturated liquid enthalpy using Eq. $16 . \ldots \ldots \ldots \ldots \ldots \ldots \ldots \ldots \ldots \ldots \ldots$

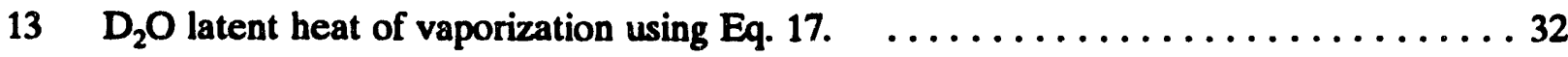

$14 \mathrm{D}_{2} \mathrm{O}$ saturated vapor enthalpy using Eq. 18. $\ldots \ldots \ldots \ldots \ldots \ldots \ldots \ldots \ldots \ldots \ldots$

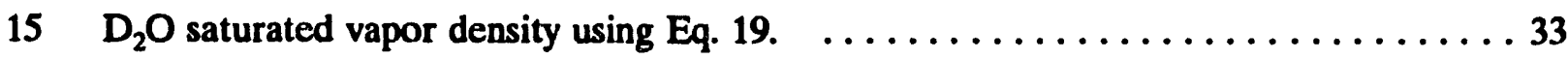

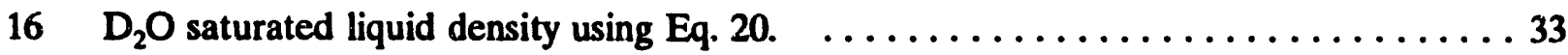

$17 \mathrm{D}_{2} \mathrm{O}$ saturated liquid thermal conductivity using Eq. $21 . \ldots \ldots \ldots \ldots \ldots \ldots \ldots$

$18 \mathrm{D}_{2} \mathrm{O}$ saturated liquid dynamic viscosity using $\mathrm{Eq} .22 . \quad \ldots \ldots \ldots \ldots \ldots \ldots \ldots \ldots$

$19 \mathrm{D}_{2} \mathrm{O}$ saturated liquid specific heat using Eq. $23 . \ldots \ldots \ldots \ldots \ldots \ldots \ldots \ldots \ldots \ldots \ldots \ldots$

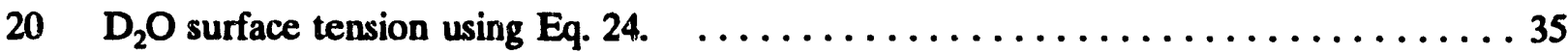

\section{LIST OF TABLES}

Page

1. Performance of the saturated light and heavy water physical

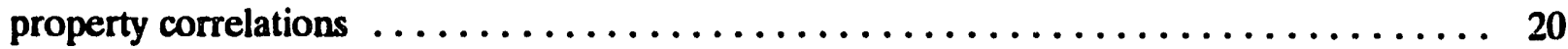

2. Sample output of the saturated light water correlations ${ }^{a} \ldots \ldots \ldots \ldots \ldots \ldots \ldots \ldots$

3. Sample output of the saturated heavy water correlations $\ldots \ldots \ldots \ldots \ldots \ldots \ldots \ldots$ 


\section{NOMENCLATURE}

\begin{tabular}{|c|c|}
\hline Cond & saturated liquid thermal conductivity $(\mathrm{W} / \mathrm{m} \cdot \mathrm{K})$ \\
\hline $\mathbf{C}_{\mathbf{p}}$ & saturated liquid specific heat $(\mathrm{kJ} / \mathrm{kg} \cdot \mathrm{K})$ \\
\hline $\begin{array}{l}\text { DynVisc } \\
\text { LiqDen }\end{array}$ & $\begin{array}{l}\text { saturated liquid dynamic viscosity (Pas) } \\
\text { saturated liquid density }\left(\mathrm{kg} / \mathrm{m}^{3}\right)\end{array}$ \\
\hline LqEntl & saturated liquid enthalpy $(\mathbf{k J} / \mathbf{k g})$ \\
\hline enHt & latent heat of vaporization $(\mathrm{kJ} / \mathrm{kg})$ \\
\hline & saturation pressure (MPa) \\
\hline Ttens & surface tension $(\mathrm{N} / \mathrm{m})$ \\
\hline & saturation temperature $\left({ }^{\circ} \mathrm{C}\right)$ \\
\hline pDen & saturated vapor density $\left(\mathrm{kg} / \mathrm{m}^{3}\right)$ \\
\hline pEntl & saturated vapor enthalpy $(\mathrm{kJ} / \mathrm{kg})$ \\
\hline
\end{tabular}




\title{
THERMOPHYSICAL PROPERTIES OF SATURATED LIGHT AND HEAVY WATER FOR ADVANCED NEUTRON SOURCE APPLICATIONS
}

\author{
Allen Crabtree \\ Moshe Siman-Tov
}

\begin{abstract}
The Advanced Neutron Source is an experimental facility being developed by Oak Ridge National Laboratory. As a new nuclear fission research reactor of unprecedented flux, the Advanced Neutron Source Reactor will provide the most intense steady-state beams of neutrons in the world. The high heat fluxes generated in the reactor $[303 \mathrm{MW}(\mathrm{t})$ with an average power density of $4.5 \mathrm{MW} / \mathrm{L}$ ] will be accommodated by a flow of heavy water through the core at high velocities. In support of this experimental and analytical effort, a reliable, highly accurate, and uniform source of thermodynamic and transport property correlations for saturated light and heavy water were developed. In order to attain high accuracy in the correlations, the range of these correlations was limited to the proposed Advanced Neutron Source Reactor's nominal operating conditions. The temperature and corresponding saturation pressure ranges used for light water were $20-300^{\circ} \mathrm{C}$ and 0.0025-8.5 MPa, respectively, while those for heavy water were 50-250 ${ }^{\circ} \mathrm{C}$ and $0.012-3.9 \mathrm{MPa}$. Deviations between the correlation predictions and data from the various sources did not exceed $1.0 \%$. Light water vapor density was the only exception, with an error of $1.76 \%$. The physical property package consists of analytical correlations, SAS codes, and FORTRAN subroutines incorporating these correlations, as well as an interactive, easy-to-use program entitled QuikProp.
\end{abstract}

\section{INTRODUCTION}

The Advanced Neutron Source (ANS) is a new research reactor facility being developed by Oak Ridge National Laboratory (ORNL) to meet the national need for an intense steady-state source of neutrons for scientific experiments. The ANS facility will include a new nuclear fission research reactor of unprecedented flux that will provide the most intense steady-state beams of neutrons in the world. The core of the reactor is composed of parallel aluminum-cladded fuel 
plates in an involute geometry. The high heat fluxes generated in the reactor [303 $\mathrm{MW}(\mathrm{t})$ with an average power density of $4.5 \mathrm{MW} / \mathrm{L}$ ] will be accommodated by a flow of heavy water through the core at very high velocities. In support of the Advanced Neutron Source Reactor (ANSR), several test facilities have been built that will simulate the conditions expected in the reactor core. Many of the thermal-hydraulic (T/H) correlations involved in the ANSR design can be derived, modified, or verified using data from these facilities.

In support of this experimental and analytical effort, it was essential to develop a reliable, highly accurate, and uniform source of thermodynamic and transport properties, especially for saturated light and heavy water to be used consistently throughout the project. After surveying the literature and realizing the heavy dependance upon computer programs for ANS calculations, it was concluded that analytical expressions (correlations) rather than tabulated values would be most useful. In order to attain high accuracy in the correlations, the range of these correlations was limited to the proposed ANSR's nominal operating conditions. The temperature and corresponding saturation pressure ranges used for light water were $20-300^{\circ} \mathrm{C}$ and $0.0025-8.5$ $\mathrm{MPa}$, respectively. For heavy water, the temperature and corresponding saturation pressure ranges were $50-250^{\circ} \mathrm{C}$ and $0.012-3.9 \mathrm{MPa}$, respectively. A goal was established to limit the maximum deviation in the correlations (compared with their relative original sources) to $3.0 \%$. In practice, however, a higher accuracy was achieved while using a single correlation for the entire range of each property. Deviations did not exceed $1.0 \%$, except for light water vapor density, for which the error was $1.76 \%$.

To ensure the reliability of the physical property correlations, only well-established sources were used. To avoid variations in the International System of Units (SI) conversions, oniy data originally tabulated in SI units were used in the correlation development. Light water physical property correlations were partly based on data taken from the American Society of Mechanical Engineers (ASME) ${ }^{1}$ steam tables. Where ASME did not provide physical properties in SI units, Keenan et al. $^{2}$ steam tables were used instead. Heavy water physical property correlations were based on Atomic Energy of Canada Limited (AECL) ${ }^{3}$ tables, with the exception of surface tension. The surface tension correlation was based on data from Vargaftik et al. ${ }^{4}$ It is worth noting that Kaizerman, Washolder, and Tomerian ${ }^{5}$ developed a functional representation of heavy water properties based on Soviet data that made use of heavy to light water property ratios. It 
was decided not to rely on such property ratios in this work but rather develop correlations based directly on the indicated tabulated values.

In the development of the physical property correlations, two software codes were used. TableCurve (Jandel Scientific, Corte Madera, California) was used primarily for determining a best fit equation for each property. SAS (SAS Institute, Inc., Cary, North Carolina) was used to fine tune the correlations and calculate the maximum deviations. These correlations were incorporated into SAS codes for determining physical property data for both light and heavy water. Since many people are not familiar with SAS, FORTRAN subroutines of these correlations were also developed that can be easily appended to other calculational programs requiring physical property data. To eliminate the need for time-consuming data searches, interpolations, and unit conversions, an easy-to-use interactive program combining light and heavy water correlations was developed. QuikProp was written in QuickBASIC (Microsoft Corporation, Redmond, Washington) but is a stand-alone executable file, thus, its use does not require compilation or the availability of QuickBASIC.

Although this effort was conducted in support of the ANS project, it is believed that the physical property correlations and the corresponding computer programs documented in this report are also useful to a broader audience. Some limitations in the correlations do exist, however, and further improvements can be made, as recommended in Sect. 6. 


\section{CORRELATION DEVELOPMENT}

In the development of the physical property correlations, several data sources were investigated to determine their reliability. The data sources and ranges selected as well as any difficulties or constraints involved in the development of the physical property correlations are discussed in this section. Explanations concerning any reservations regarding confidence levels or source selections are also included in this section.

\subsection{LIGHT WATER CORREILATION DEVELOPMENT}

The light water physical property correlations are applicable over a temperature range of $20-300^{\circ} \mathrm{C}$ and a corresponding saturated pressure range of $0.0025-8.5 \mathrm{MPa}$. These light water physical property correlations are partly based on data taken from the ASME ${ }^{1}$ steam tables. The surface tension correlation is an exact formulation as recommended by ASME. Where ASME did not provide physical properties in SI units, Keenan et al. ${ }^{2}$ steam tables were used. Each correlation, its respective source, and maximum deviation from the data are further documented in Sect. 3. The light water physical property correlations developed deviate no more than $\mathbf{0 . 7 \%}$ when compared with tabulated values of their respective sources, with the exception of saturated vapor density, which deviates $1.76 \%$.

Most light water physical property correlations were developed using the exact tabulated values with no unit conversions, extrapolations, or interpolations. The development of the liquid dynamic viscosity correlation, however, did require some manipulation. The ASME values are not tabulated for saturated conditions but rather as a function of both temperature and pressure. Of these values, only nine were within the applicable range of the correlation. In order to determine the liquid dynamic viscosity at saturation conditions, two successive viscosity values at a given temperature were used to extrapolate back to the saturation pressure conditions corresponding to that temperature.

The light water physical property correlations incorporated all data available from their respective sources over the applicable range. With the exception of liquid dynamic viscosity, ASME values are tabulated in ten-degree intervals, while Keenan et al. ${ }^{2}$ values are in five-degree intervals. Consequently, the correlations using Keenan et al. ${ }^{2}$ data result in slightly higher statistical confidence levels. 
Although an exact formulation as recommended by ASME is used as the surface tension correlation, an attempt was made to reduce the maximum deviation by determining new constants. New constants were determined by narrowing the original range of the correlation to that of the applicable range. Although a maximum deviation of $0.3 \%$ was attained using the new constants as opposed to $0.5 \%$ using the original, this improvement was not considered appreciable, and the original constants were retained.

\section{HEAVY WATER CORRELATION DEVELOPMENT}

The heavy water physical property correlations are applicable over a temperature range of $50-250^{\circ} \mathrm{C}$ and a corresponding saturated pressure range of $0.012-3.9 \mathrm{MPa}$. These heavy water physical property correlations were based entirely on data taken from the Atomic Energy of Canada Limited (AECL), ${ }^{3}$ with the exception of surface tension. The surface tension correlation is an exact formulation taken from Vargaftik et al. ${ }^{4}$ Each correlation, its respective source, and maximum deviation from the data is further documented in Sect. 3. The heavy water physical property correlations developed deviate no more than $1.0 \%$ when compared with the tabulated values of their respective sources.

With the exceptions of liquid thermal conductivity, liquid dynamic viscosity, and surface tension, all of the heavy water physical property correlations were developed using the exact tabulated values as given in the AECL tables, with no unit conversions, extrapolations, or interpolations. The liquid thermal conductivity values found in the AECL source are not tabulated for saturated conditions but rather as a function of both temperature and pressure. Of these values, only six were within the applicable range of the correlation. In order to determine the liquid thermal conductivity at saturation conditions, two successive conductivity values at a given temperature were used to extrapolate back to the saturation pressure conditions corresponding to that temperature.

In the development of the heavy water liquid dynamic viscosity correlation, it was discovered that the AECL tables did not include values for dynamic viscosity but instead provided two kinematic viscosity tables. ${ }^{6}$ In the absence of dynamic viscosity tables, it was first necessary to determine the saturated kinematic viscosity and then convert to dynamic viscosity by multiplying by the corresponding density. As with liquid thermal conductivity, the liquid kinematic viscosity values are not tabulated for saturated conditions but rather as a function of both temperature and pressure. Of these values, only six were within the applicable range of the correlation. In order to 
obtain the saturated liquid kinematic viscosity at saturation conditions, two successive kinematic viscosity values at a given temperature were used to extrapolate back to the saturation pressure conditions corresponding to that temperature. Once the saturated liquid kinematic viscosity values were obtained, interpolation was required to determine the saturated liquid density for the corresponding saturation temperature. The saturated liquid kinematic viscosity values were then multiplied by their corresponding saturated liquid density values to obtain the saturated liquid dynamic viscosity. To confirm that all of these manipulations were performed correctly, the resulting saturated liquid dynamic viscosity values were compared with values provided by Heiks et al. ${ }^{7}$ This comparison showed good agreement within a maximum deviation of $3.0 \%$.

With the exception of surface tension, the heavy water physical property correlations incorporated all of the available AECL data in the applicable range. In most cases, the physical property correlations are based on property values that are tabulated in five-degree intervals. As a result, these correlations often yield statistically higher confidence levels. As previously mentioned, however, the liquid thermal conductivity and liquid dynamic viscosity correlations were based on only six values that were within the applicable range. Although these correlations yield a lower confidence level, this lower level does not reflect badly on the correlations' performance since the data trends are smooth. 


\section{ANALYTICAL CORREL/ITIONS}

In the following pages, the actual light and heavy water physical property correlations are presented. Although most of the property values are in SI units, it proved to be more convenient to use megapascals and kilojoules instead of the formal SI units of Pascals and joules. The correlations' maximum deviations from the data and their respective sources are listed in Table 1 at the end of this chapter. In order to attain the accuracy as stated in Table 1, the coefficients must be applied exactly as they appear. Any alteration, including truncation, of the coefficients will cause a noticeable change in the accuracy of the resulting property values.

Although the physical property correlations for saturated heavy water were originally developed for a $50-250^{\circ} \mathrm{C}$ temperature range, we have also examined the correlations' performance over an extended range. The correlations were checked both at $45^{\circ}$ and $35^{\circ} \mathrm{C}$. A five-degree extension of the temperature range resulted in minor error increases. In some cases, the error at $45^{\circ} \mathrm{C}$ was lower than the maximum deviation in the original range. The extension of the correlations to $35^{\circ} \mathrm{C}$ resulted in slight error increases.

Errors were not reported at either temperature for saturated heavy water thermal conductivity and dynamic viscosity because these properties were already valid for temperatures as low as $26.84^{\circ} \mathrm{C}$. Errors for saturated liquid specific heat were not reported because there were no data for saturated specific heat below $47.93^{\circ} \mathrm{C}$ in the $\mathrm{AECL}^{3}$ data. Although one would not expect a major increase in the error of saturated liquid specitic heat at $45^{\circ} \mathrm{C}$, it is not known whether the error at $35^{\circ} \mathrm{C}$ would be small. Where data were available, the maximum deviations were 0.33 and $1.68 \%$ at 45 and $35^{\circ} \mathrm{C}$, respectively. 


\subsection{PHYSICAL PROPERTY CORRELATIONS FOR SATURATED LIGHT WATER}

The physical property correlations for saturated light water are applicable over a temperature range of $20-300^{\circ} \mathrm{C}$. This temperature range corresponds to a pressure range of 0.0025-8.5 MPa.

$\mathrm{H}_{2} \mathrm{O}$ SATURATION TEMPERATURE (as a function of pressure)

$$
T_{\text {ses }}=(A+C X) /\left(1+B X+D X^{2}\right) \text {, }
$$

where

$$
\begin{aligned}
& X=\ln (\mathrm{P}) \\
& A=179.9600321 \\
& B=-0.1063030 \\
& C=24.2278298 \\
& D=2.951 \times 10^{-4} \\
& P=\text { absolute pressure }(\mathrm{MPa}), \\
& T_{\text {sal }}\left({ }^{\circ} \mathrm{C}\right) .
\end{aligned}
$$

$\mathrm{H}_{2} \mathrm{O}$ SATURATION TEMPERATURE (as a function of saturated liquid enthalpy)

$$
T_{\text {sat }}=A+B h+C h^{5 / 2}+D h^{3},
$$

where

$$
\begin{aligned}
& A=0.0835777361 \\
& B=0.2377936769 \\
& C=5.1932951 \times 10^{-7}, \\
& D=-2.2208153 \times 10^{-8}, \\
& h=\text { liquid enthalpy }(\mathrm{kJ} / \mathrm{kg}) \\
& T_{\text {sat }}\left({ }^{\circ} \mathrm{C}\right) .
\end{aligned}
$$




\section{$\mathrm{H}_{\mathbf{2}} \mathrm{O}$ SATURATION PRESSURE}

$$
P_{\infty \infty}=\exp \left[\left(A+C T+E T^{2}\right) /\left(1+B T+D T^{2}+F T^{3}\right)\right],
$$

where

$$
\begin{aligned}
& A=-7.395489709, \\
& B=4.884152 \times 10^{-3}, \\
& C=3.6337285 \times 10^{-2}, \\
& D=4.308960 \times 10^{-6}, \\
& E=2.651419 \times 10^{-5}, \\
& F=-4.14934 \times 10^{-9}, \\
& T=\text { temperature }\left({ }^{\circ} \mathrm{C}\right), \\
& P_{\text {so }} \text { (MPa). }
\end{aligned}
$$

\section{H2O SATURATED LIQUID ENTHALPY}

$$
L q E n t l=\left(A+C T+E T^{2}\right) /\left(1+B T+D T^{2}\right),
$$

where

$$
\begin{aligned}
& A=0.786889159, \\
& B=-0.001874457, \\
& C=4.163042560, \\
& D=-3.334 \times 10^{-7}, \\
& E=-0.007798602, \\
& T=\text { temperature }\left({ }^{\circ} \mathrm{C}\right) \\
& \text { LqEntl }(\mathrm{kJ} / \mathrm{kg}) .
\end{aligned}
$$

\section{$\mathrm{H}_{2} \mathrm{O}$ LATENT HEAT OF VAPORIZATION}

$$
L \operatorname{tn} H t=\left(A+B T+C T^{2}+D T^{3}\right)^{1 / 2},
$$

where

$$
\begin{aligned}
& A=6254828.560, \\
& B=-11742.337953, \\
& C=6.336845, \\
& D=-0.049241, \\
& T=\text { temperature }\left({ }^{\circ} \mathrm{C}\right), \\
& \text { LmHt }(\mathrm{kJ} / \mathrm{kg}) .
\end{aligned}
$$




\section{H2O SATURATED VAPOR ENTHALPY}

$$
\text { VapEntl }=A+B T^{\$ / 2}+C T^{3}+D T^{1 / 2}[\ln (T)],
$$

where

$$
\begin{aligned}
& A=2488.301071, \\
& B=6.2698272 \times 10^{-4}, \\
& C=-3.953072 \times 10^{-5}, \\
& D=3.562872385, \\
& T=\text { temperature }\left({ }^{\circ} \mathrm{C}\right), \\
& \text { VapEntl (kJ/kg). }
\end{aligned}
$$

\section{H ${ }_{2} \mathrm{O}$ SATURATED VAPOR DENSITY}

$$
\text { VapDen }=\left(A+C T+E T^{2}+G T^{3}\right) /\left(1+B T+D T^{2}+F T^{3}+H T^{4}\right),
$$

where

$$
\begin{aligned}
& A=-4.375094 \times 10^{-4}, \\
& B=-6.947700 \times 10^{-3}, \\
& C=7.662589 \times 10^{-4}, \\
& D=2.418897 \times 10^{-5} \\
& E=-5.963920 \times 10^{-6} \\
& F=-4.227966 \times 10^{-8} \\
& G=2.867976 \times 10^{-7} \\
& H=2.594175 \times 10^{-11} \\
& T=\text { temperature }\left({ }^{\circ} \mathrm{C}\right) \\
& \text { VapDen (kg/m }) .
\end{aligned}
$$

\section{H2O SATURATED LQUID DENSITY}

$$
\text { LiqDen }=\left(A+B T_{F}+C T_{P}^{2}\right),
$$

where

$$
\begin{aligned}
& T_{F}=1.8 \mathrm{~T}+32, \\
& A=1004.789042, \\
& B=-0.046283, \\
& C=-7.9738 \times 10^{-4}, \\
& T=\text { temperature }\left({ }^{\circ} \mathrm{C}\right), \\
& \text { LiqDen }\left(\mathrm{kg} / \mathrm{m}^{3}\right) .
\end{aligned}
$$


H$_{2} \mathrm{O}$ SATURATED LIQUID THERMAL CONDUCTIVITY

$$
\text { Cond }=\left(A+B T+C T^{2}+D T^{3}\right),
$$

where

$$
\begin{aligned}
& A=0.5677829144, \\
& B=1.8774171 \times 10^{-3}, \\
& C=-8.1790 \times 10^{-6}, \\
& D=5.66294775 \times 10^{-9}, \\
& T=\text { temperature }\left({ }^{\circ} \mathrm{C}\right), \\
& C \text { ond }(\mathrm{W} / \mathrm{m} \cdot \mathrm{K}) .
\end{aligned}
$$

\section{$\mathrm{H}_{2} \mathrm{O}$ SATURATED LUUID DYNAMIC VISCOSITY}

$$
\text { DynVisc }=\exp \left[(A+C T) /\left(1+B T+D T^{2}\right)\right],
$$

where

$$
\begin{aligned}
& A=-6.325203964, \\
& B=8.705317 \times 10^{-3}, \\
& C=-0.088832314, \\
& D=-9.657 \times 10^{-7}, \\
& T=\text { temperature }\left({ }^{\circ} \mathrm{C}\right), \\
& \text { DynVisc (Paes). }
\end{aligned}
$$

\section{H$_{2}$ O SATURATED LIQUID SPECIFIC HEAT}

$$
C_{P}=\left[(A+C T) /\left(1+B T+D T^{2}\right)\right]^{1 / 2},
$$

where

$$
\begin{aligned}
& A=17.48908904, \\
& B=-1.67507 \times 10^{-3}, \\
& C=-0.03189591, \\
& D=-2.8748 \times 10^{-6}, \\
& T=\text { temperature }\left({ }^{\circ} \mathrm{C}\right), \\
& C_{p}(\mathrm{~kJ} / \mathrm{kg} \cdot \mathrm{K}) .
\end{aligned}
$$


$\mathrm{H}_{2} \mathrm{O}$ SURFACE TENSION

$$
\text { Sftens }=A X^{\circledR}(1+C X),
$$

where

$$
\begin{aligned}
& X=(373.99-\mathrm{T}) / 647.15, \\
& A=235.8 \times 10^{-3}, \\
& B=1.256, \\
& C=-0.625, \\
& T=\text { temperature }\left({ }^{\circ} \mathrm{C}\right), \\
& \text { Sfiens }(\mathrm{N} / \mathrm{m}) .
\end{aligned}
$$




\section{PHYSICAL PROPERTY CORREIATIONS FOR SATURATED HEAVY WATER}

The physical property correlations for saturated heavy water are applicable over a temperature range of $50-250^{\circ} \mathrm{C}$. This temperature ranges corresponds to a pressure range of 0.012-3.9 $\mathrm{MPa}$.

D 2 SATURATION TEMPERATURE (as a function of pressure)

$$
T_{\text {sat }}=\exp \left(A+B X+C X^{2}+D X^{3}\right) \text {, }
$$

where

$$
\begin{aligned}
& X=\ln (\mathrm{P}) \\
& A=5.194927982 \\
& B=0.236771673 \\
& C=-2.615268 \times 10^{-3}, \\
& D=1.708386 \times 10^{-3}, \\
& P=\text { absolute pressure }(\mathrm{MPa}) \\
& T_{\text {sat }}\left({ }^{\circ} \mathrm{C}\right) .
\end{aligned}
$$

D 2 O SATURATION TEMPERATURE (as a function of saturated liquid enthalpy)

$$
T_{e x}=A+B h[\ln (h)]+C h^{2}[\ln (h)] \text {, }
$$

where

$$
\begin{aligned}
& A=11.34352515 \\
& B=0.03875871, \\
& C=-5.733 \times 10^{-6}, \\
& h=\text { liquid enthalpy }(\mathrm{kJ} / \mathrm{kg}), \\
& T_{\text {sax }}\left({ }^{\circ} \mathrm{C}\right) .
\end{aligned}
$$




\section{20 SATURATION PRESSURE}

$$
P_{\text {eat }}=\exp \left(A+B / T_{K}+C \times \ln \left(T_{K}\right)+D T_{K}\right),
$$

where

$$
\begin{aligned}
& T_{K}=\mathrm{T}+273.16 \\
& A=95.720020 \\
& B=-8439.4 \% 0752 \\
& C=-13.496506 \\
& D=0.012010 \\
& T=\text { temperature }\left({ }^{\circ} \mathrm{C}\right) \\
& P_{\text {sat }}(\mathrm{MPa}) .
\end{aligned}
$$

\section{D2O SATURATED LIQUID ENTHALPY}

$$
L q E n t l=A+B T^{2}+C T / \ln (T),
$$

where

$$
\begin{aligned}
& A=-81.40815291 \\
& B=0.00274496 \\
& C=21.13005836 \\
& T=\text { temperature }\left({ }^{\circ} \mathrm{C}\right), \\
& \text { LiqEntl }(\mathrm{kJ} / \mathrm{kg}) .
\end{aligned}
$$

\section{D $_{2}$ O LATENT HEAT OF VAPORIZATION}

$$
L \text { tnHt }=\left(A+B X+C X^{2}\right)^{1 / 2},
$$

where

$$
\begin{aligned}
& X=371.49-\mathrm{T}, \\
& A=508093.6669, \\
& B=17006.921765, \\
& C=-11.009078, \\
& T=\text { temperature }\left({ }^{\circ} \mathrm{C}\right), \\
& \text { LthHt }(\mathrm{kJ} / \mathrm{kg}) .
\end{aligned}
$$


D2O SATURATED VAPOR ENTHALPY

$$
V a p E n t l=A+B T[\ln (T)]+C T^{3},
$$

where

$$
\begin{aligned}
& A=2337.404845, \\
& B=0.335900, \\
& C=-1.30643 \times 10^{-5}, \\
& T=\text { temperature }\left({ }^{\circ} \mathrm{C}\right), \\
& \text { VapEntl }(\mathrm{kJ} / \mathrm{kg}) .
\end{aligned}
$$

\section{$\mathrm{D}_{2} \mathrm{O}$ SATURATED VAPOR DENSITY}

$$
\text { VapDen }=\exp \left[\left(A+C T+E T^{2}\right) /\left(1+B T+D T^{2}\right)\right],
$$

where

$$
\begin{aligned}
& A=-5.456208705 \\
& B=2.386228 \times 10^{-3}, \\
& C=0.060526809 \\
& D=-1.15778 \times 10^{-5}, \\
& E=-1.11360 \times 10^{-4} \\
& T=\text { temperature }\left({ }^{\circ} \mathrm{C}\right) \\
& \text { VapDen }\left(\mathrm{kg} / \mathrm{m}^{3}\right) .
\end{aligned}
$$

\section{D $_{2} \mathrm{O}$ SATURATED LIQUID DENSITY}

$$
\text { LiqDen }=\left(A+B T_{P}+C T_{F}^{2}\right),
$$

where

$$
\begin{aligned}
& T_{F}=1.8 \mathrm{~T}+32, \\
& A=1117.772605, \\
& B=-0.077855 \\
& C=-8.42 \times 10^{-4}, \\
& T=\text { temperature }\left({ }^{\circ} \mathrm{C}\right), \\
& \text { LiqDen }\left(\mathrm{kg} / \mathrm{m}^{3}\right) .
\end{aligned}
$$




\section{$\mathrm{D}_{2} \mathrm{O}$ SATURATED LIQUID THERMAL CONDUCTIVITY}

$$
\text { Cond }=\left(A+B T_{1}+C T_{1}^{2}+D T_{1}^{3}\right),
$$

where

$$
\begin{aligned}
& T_{1}=(1.8 \mathrm{~T}+491.67) \times 10^{-4}, \\
& A=-0.4521496, \\
& B=36.0743280 \\
& C=-357.9973221, \\
& D=924.0219962, \\
& T=\text { temperature }\left({ }^{\circ} \mathrm{C}\right), \\
& C \text { ond }(\mathrm{W} / \mathrm{m} \bullet \mathrm{K}) .
\end{aligned}
$$

\section{D2O SATURATED LIQUID DYNAMIC VISCOSITY}

$$
\text { DynVisc }=\left(A+B T_{F}+C / T_{F}+D / T_{P} 2\right),
$$

where

$$
\begin{aligned}
& T_{F}=1.8 \mathrm{~T}+32, \\
& A=-1.111606 \times 10^{-4}, \\
& B=9.46 \times 10^{-8}, \\
& C=0.0873655375 \\
& D=0.4111103409, \\
& T=\text { temperature }\left({ }^{\circ} \mathrm{C}\right) \\
& \text { DynVisc (Paes). }
\end{aligned}
$$

\section{D2O SATURATED LIQUID SPECIFIC HEAT}

$$
C_{P}=\left(A+B T_{1}+C T_{1}^{2}+D T_{1}^{3}\right),
$$

where

$$
\begin{aligned}
& T_{1}=(1.8 \mathrm{~T}+491.67) \times 10^{-4} \\
& A=2.237124 \\
& B=122.217151 \\
& C=-2303.384060 \\
& D=13555.737878 \\
& T=\text { temperature }\left({ }^{\circ} \mathrm{C}\right) \\
& C_{P}(\mathrm{~kJ} / \mathrm{kg} \cdot \mathrm{K}) .
\end{aligned}
$$




\section{$\mathrm{D}_{2} \mathrm{O}$ SURFACE TENSION}

$$
\text { Sftens }=A X^{B}(I+C X),
$$

where

$$
\begin{aligned}
& X=(371.49-\mathrm{T}) / 644.65, \\
& A=2.44835759 \times 10^{-1}, \\
& B=1.269 \\
& C=-6.60709649 \times 10^{-1}, \\
& T=\text { temperature }\left({ }^{\circ} \mathrm{C}\right), \\
& \text { Sftens }(\mathrm{N} / \mathrm{m}) .
\end{aligned}
$$




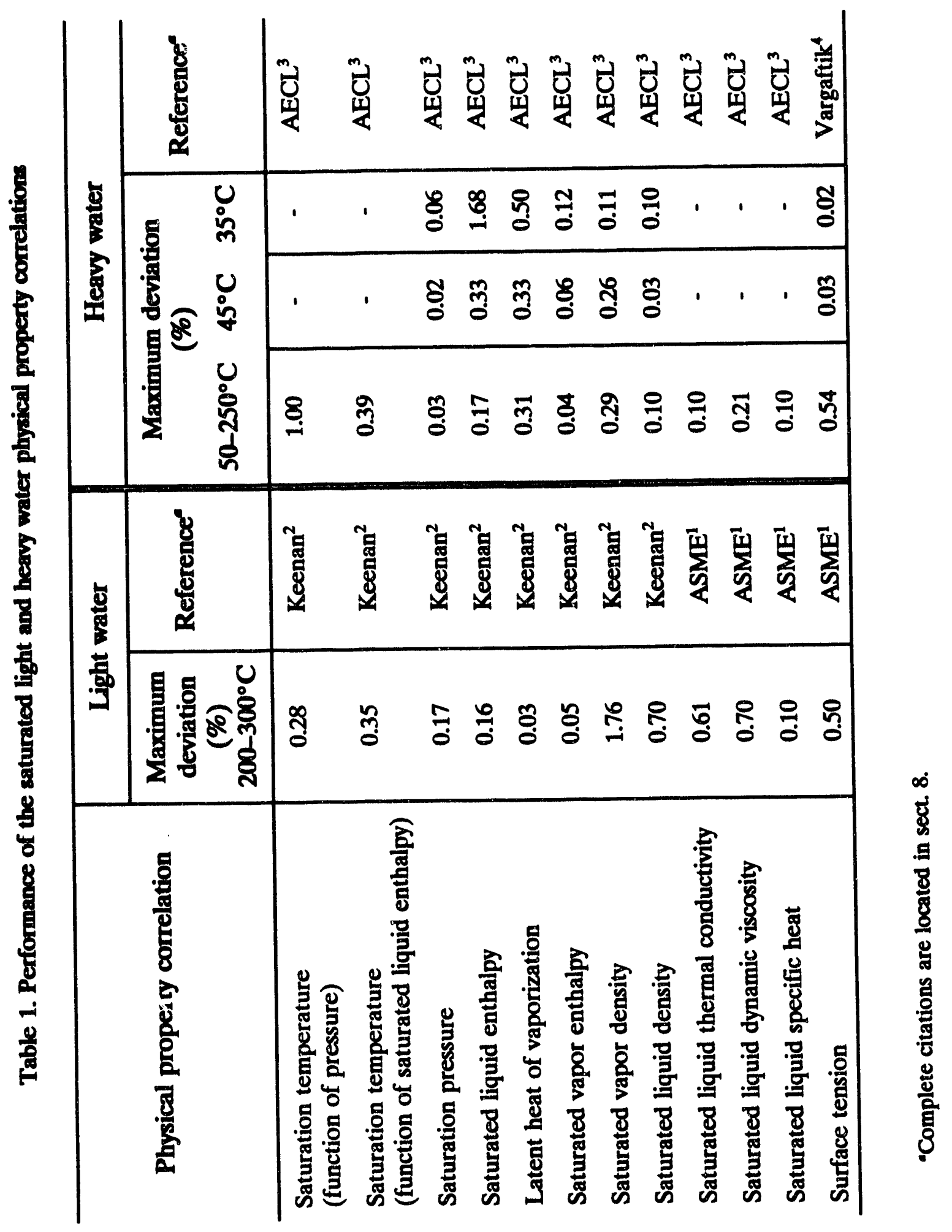




\section{PHYSICAL PROPERTY COMPUTER CODES}

The physical property correlations were incorporated in three different codes using three different programming languages. The most extensive code was an interactive properties software package that was developed using QuickBASIC. The most versatile code was a pair of FORTRAN subroutines that can be easily appended to any FORTRAN code. The correlations were also organized in a third code providing SAS users a means of Jetermining physical property data.

\subsection{QUIKPROP}

A convenient, quick, and easy to use interactive properties software package was developed using the physical property correlations. Although written in QuickBASIC, QuikProp is a standalone executable code and does not require QuickBASIC for execution. The correlations used in the code are exactly as they appear in Sect. 3. The program can accept both temperatures and pressures in either British or SI units. No preinstruction is necessary because the user is guided through the program. It was our intent for this program to provide the user with a "quick" source of physical properties, thus alleviating the need for time consuming interpolations and unit conversions.

\subsection{FORTRAN SUBROUTINES}

FORTRAN subroutines have been developed that can be easily incorporated in existing FORTRAN codes. Usually this requires no more than the addition of a call statement in the original code. As with the interactive properties package, all correlations used in the subroutines are exactly as they appear in Sect. 3. The subroutines calculate physical properties and pass them to the main program as double-precision values. As a word of caution, the subroutines often provide inaccurate values if a double-precision input value is not passed to the subroutine. If single-precision values are desired, the variable declarations statement in the physical property subroutines must be changed accordingly. 


\subsection{SAS PROGRAMS}

Unlike FORTRAN, SAS is not a very common programming language. SAS, however, was used in the development of the physical property correlations, and as a result, the first physical property codes were written in SAS. As with all the other physical property codes, the correlations used in their development are exactly as they appear in Sect. 3. The initial point, final point, and interval are defined at the top of the code using macro variables. The properties are then calculated, and the results are displayed in the output window in a tabular format.

The authors will be glad to provide a copy of these codes upon request. If you are interested, please contact Allen Crabtree [(615) 576-5298] or Moshe Siman-Tov [(615) 574-6515]. 


\section{PHYSICAL PROPERTY TABLES AND GRAPHS}

The tables and graphs in this section are provided as an additional description of the correlations and their performance. Table 2 is followed by Figs. 1-10 for selected saturated light water properties, while Table 3 is followed by Figs. 11-20 for selected saturated heavy water properties. The tables are sample outputs from the property codes described in Sect. 4 and are not suggested for uses other than point calculations or comparisons. As a visual representation of the physical property correlations, the graphs reflect any trends that the properties may have as a function of temperature. The computer codes described in Sect. 4 are highly recommended for any additional computations and are readily available from the authors. If these codes are not adequate for a particular application and the user wishes to incorporate the correlations himself, the sample output results will serve as an excellent means of checking accuracy. 


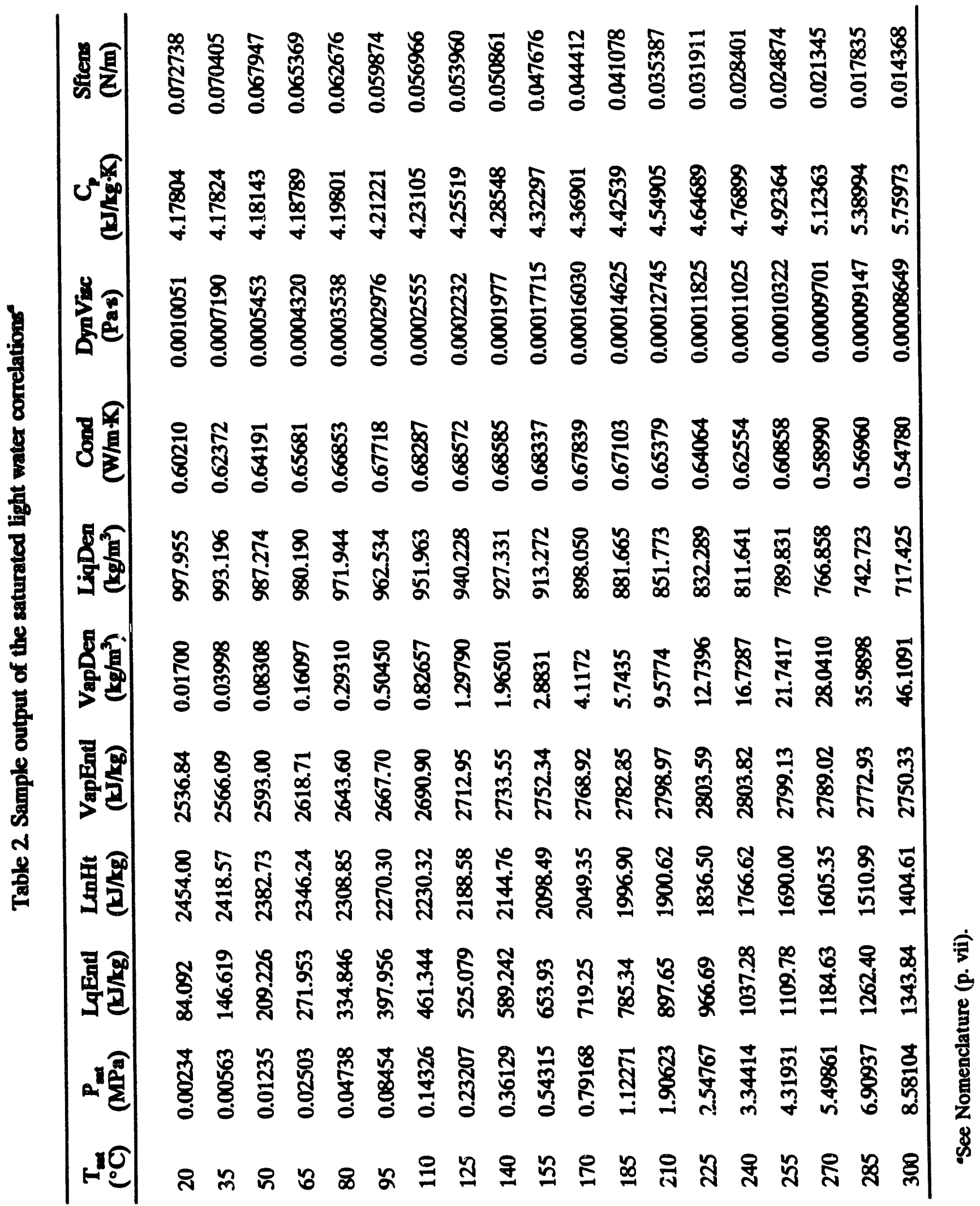




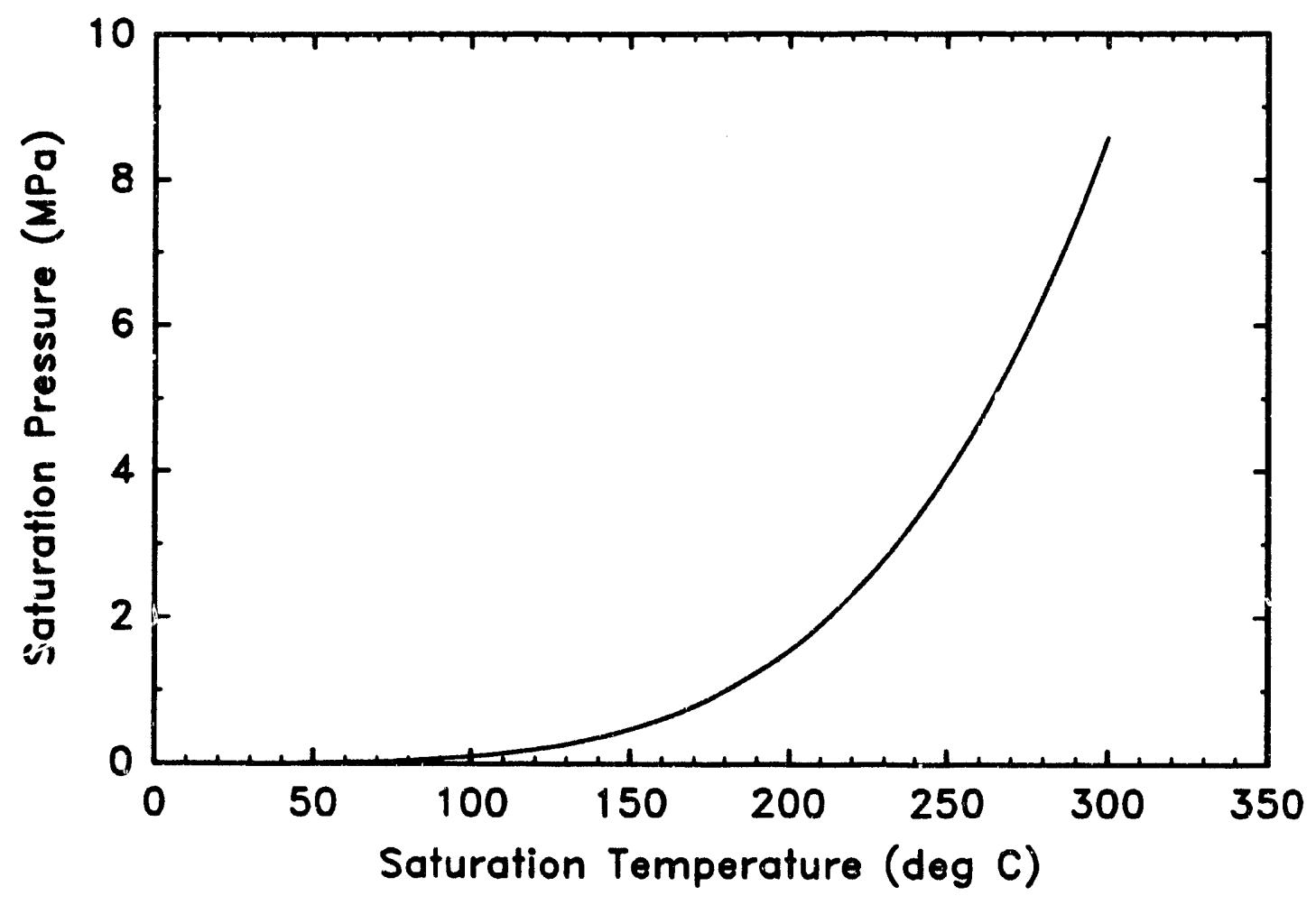

Fig. 1. $\mathrm{H}_{2} \mathrm{O}$ saturation pressure using Eq. 3.

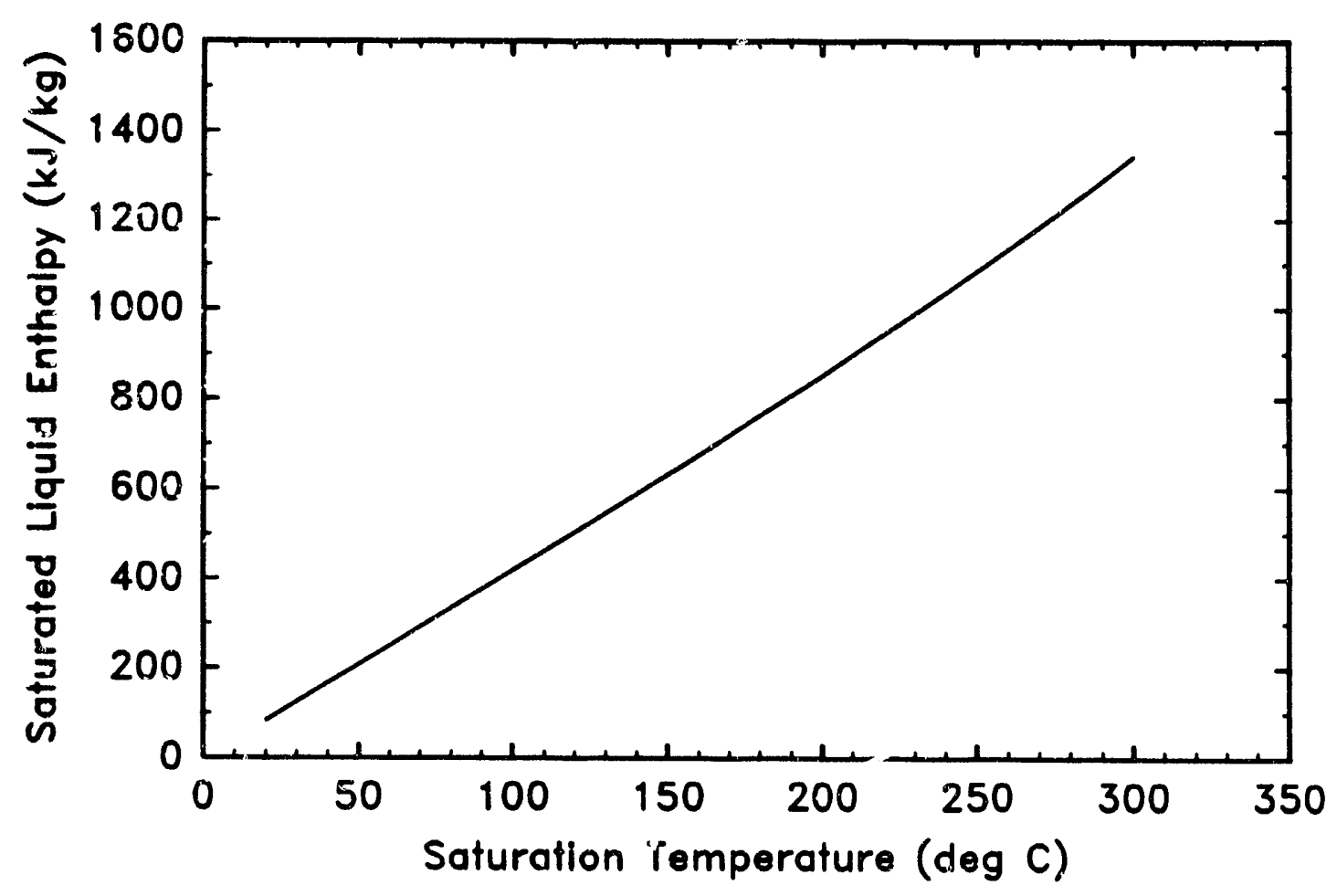

Fig. $2 \mathrm{H}_{2} \mathrm{O}$ saturated liquid enthalpy issing Eq. 4. 


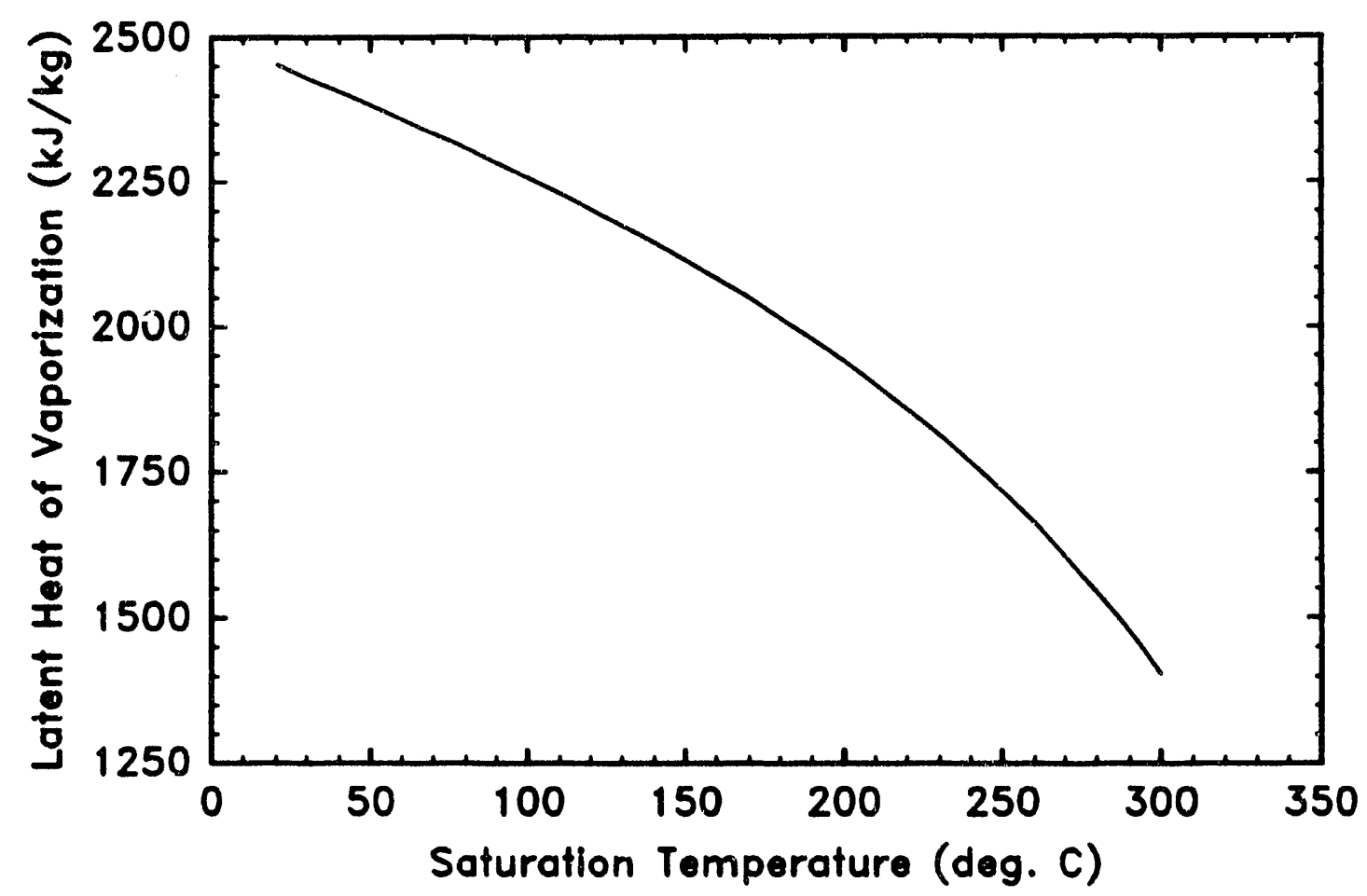

Fig. 3. $\mathrm{H}_{2} \mathrm{O}$ latent heat of vaporization using $\mathrm{Eq} .5$.

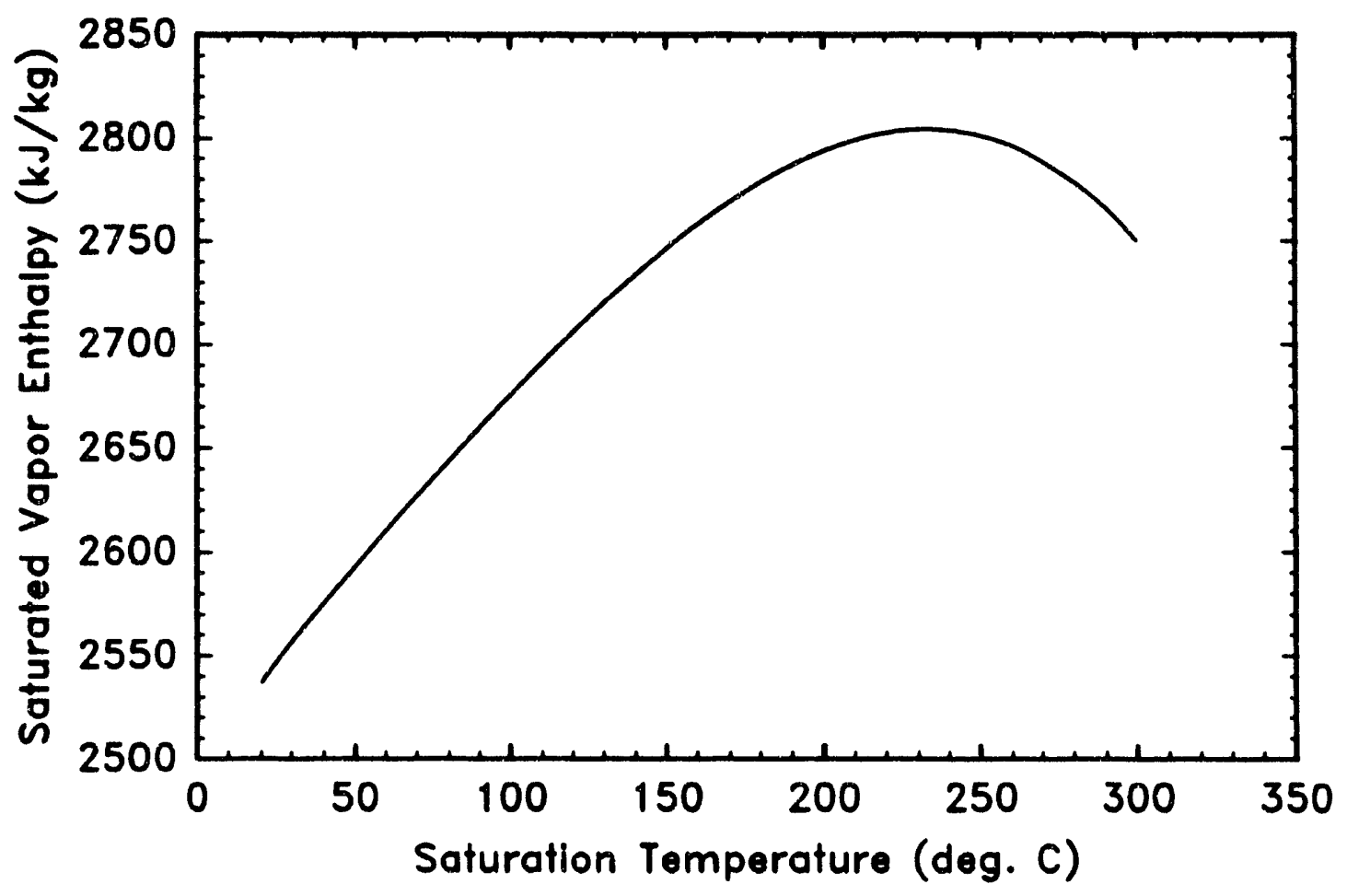

Fig. 4. $\mathrm{H}_{2} \mathrm{O}$ saturated vapor enthalpy using $\mathrm{Eq}$. 6 . 


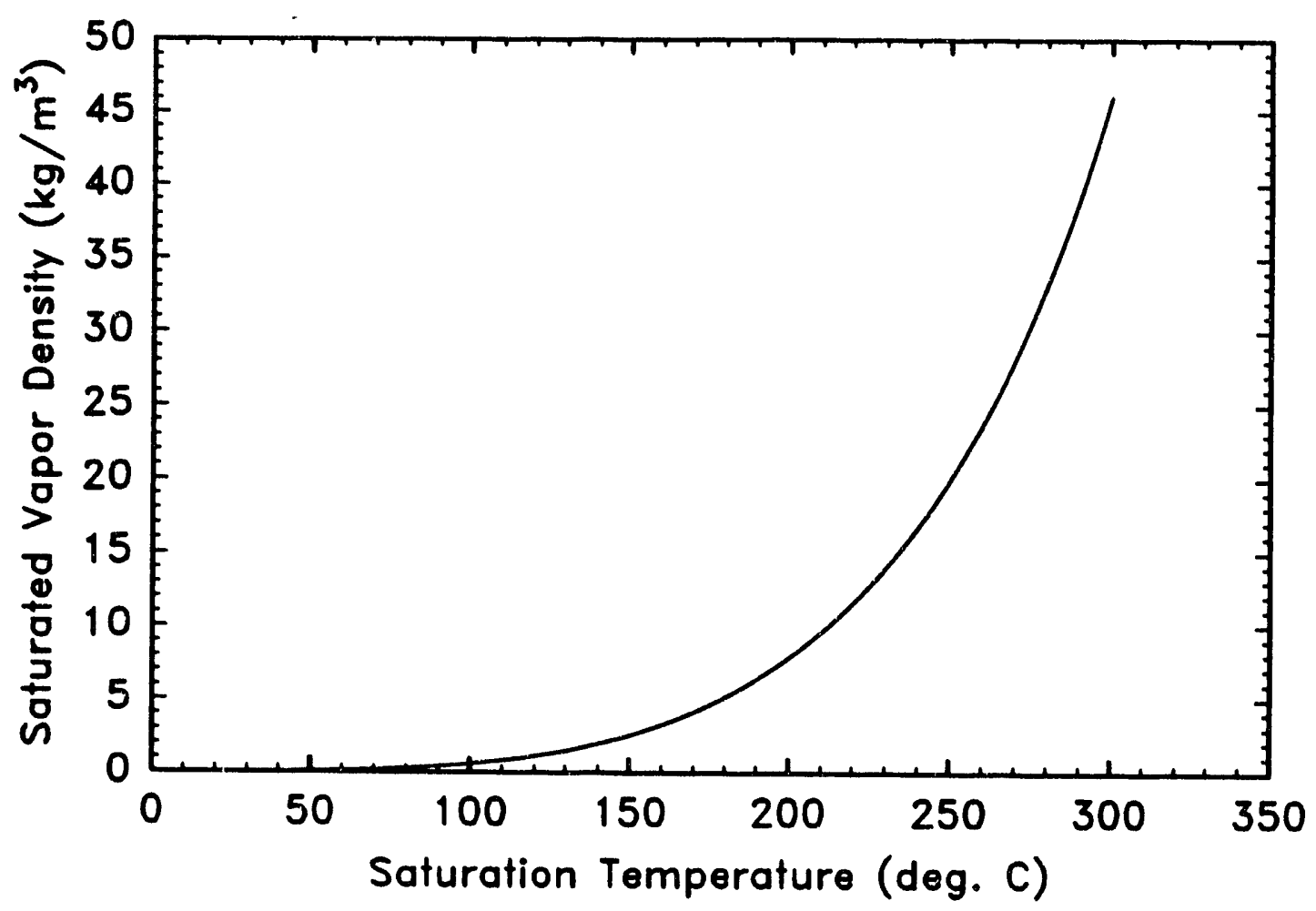

Fig. 5. $\mathrm{H}_{2} \mathrm{O}$ saturated vapor density using Eq. 7 .

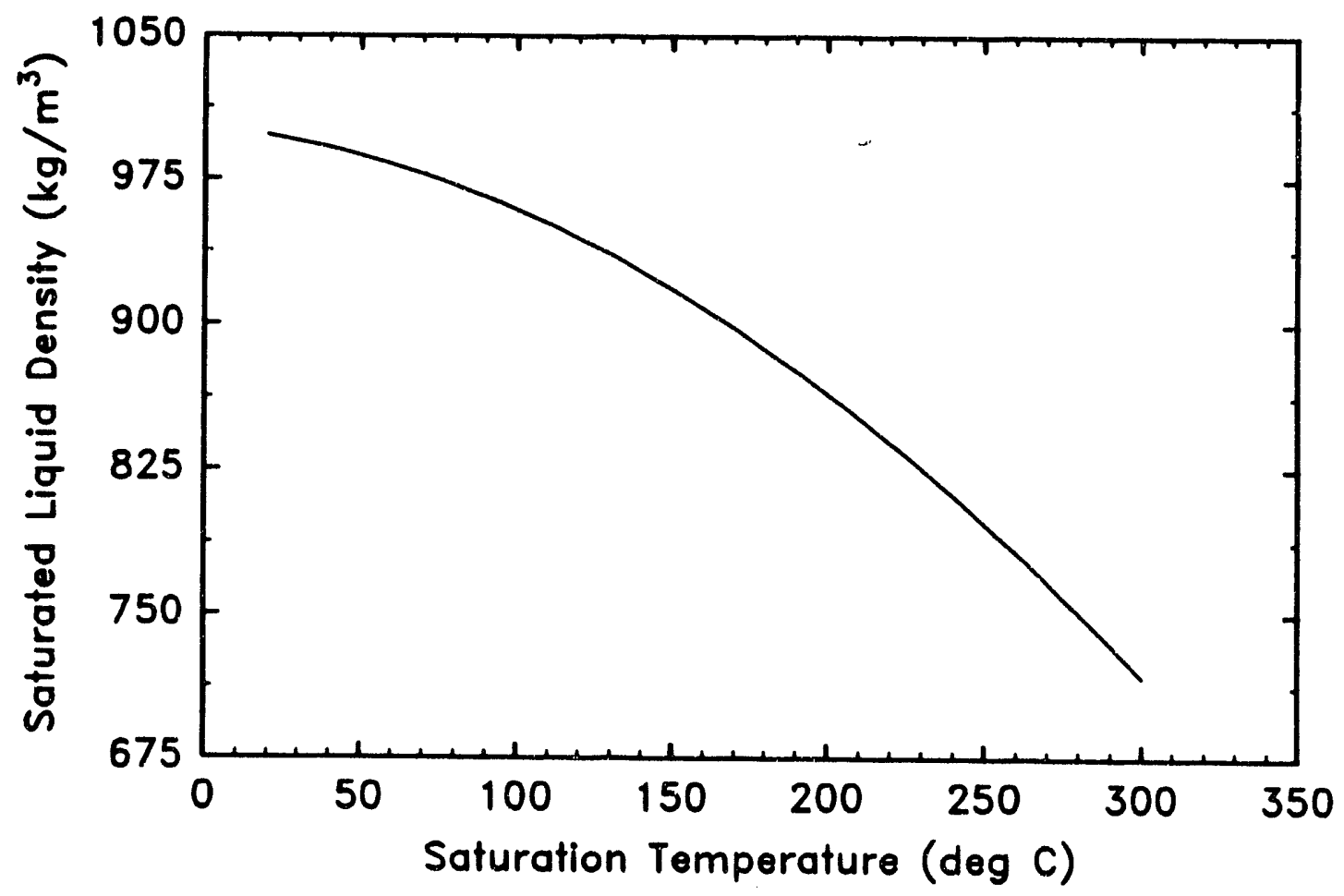

Fig. 6. $\mathrm{H}_{2} \mathrm{O}$ saturated liquid density using Eq. 8. 


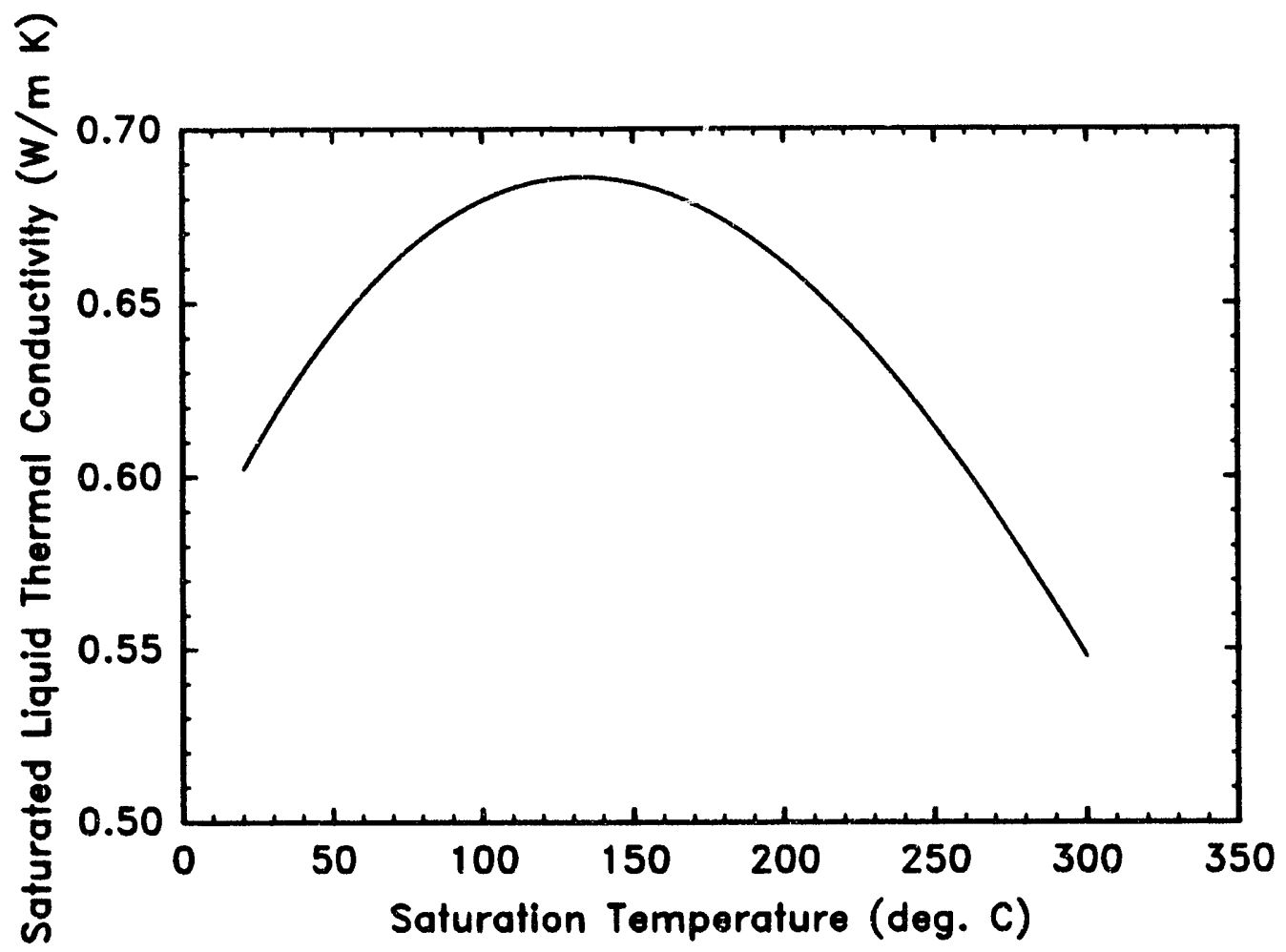

Fig. 7. $\mathrm{H}_{2} \mathrm{O}$ saturated liquid thermal conductivity using Eq. 9.

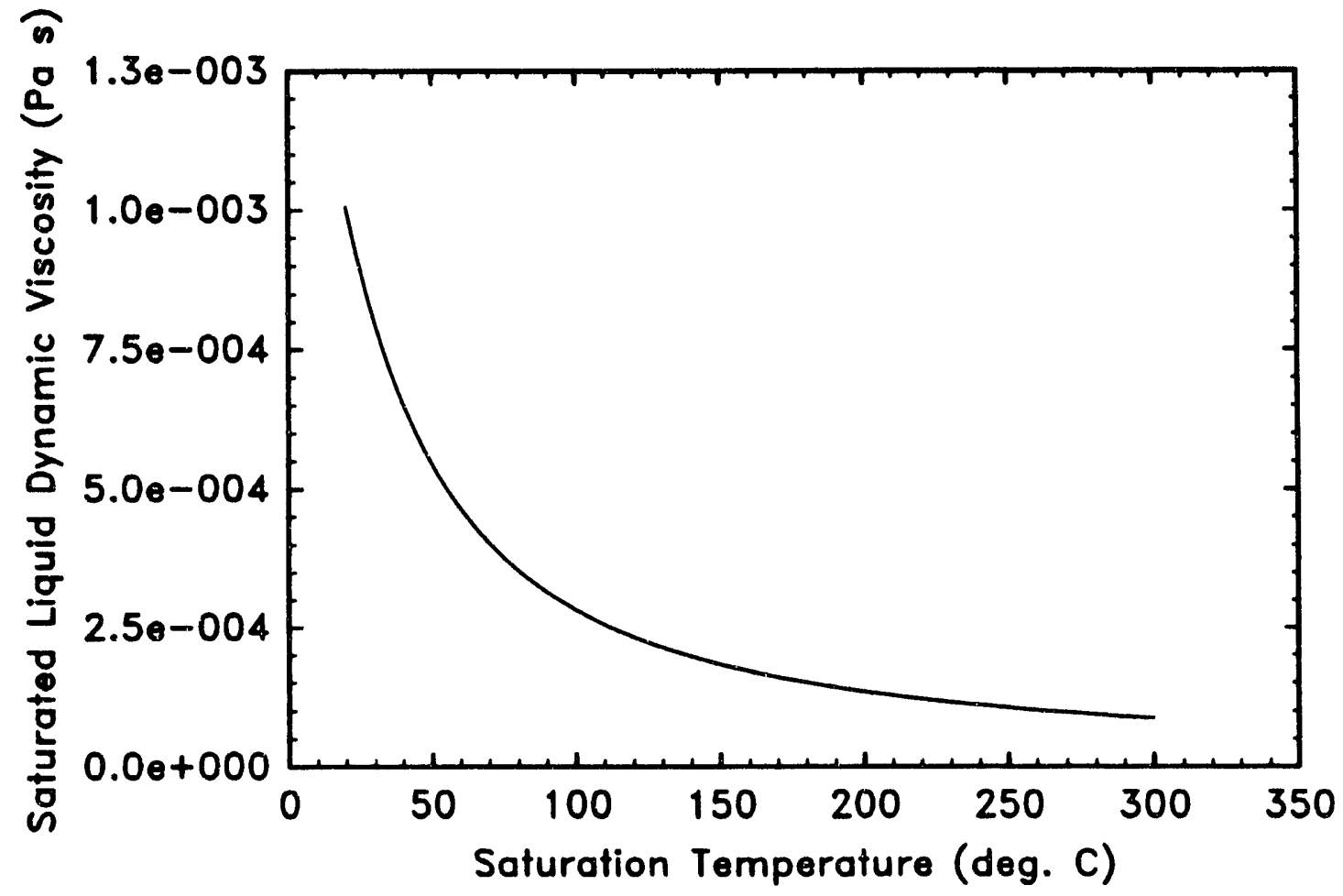

Fig. 8. $\mathrm{H}_{2} \mathrm{O}$ saturated liquid dynamic viscosity using Eq. 10 . 


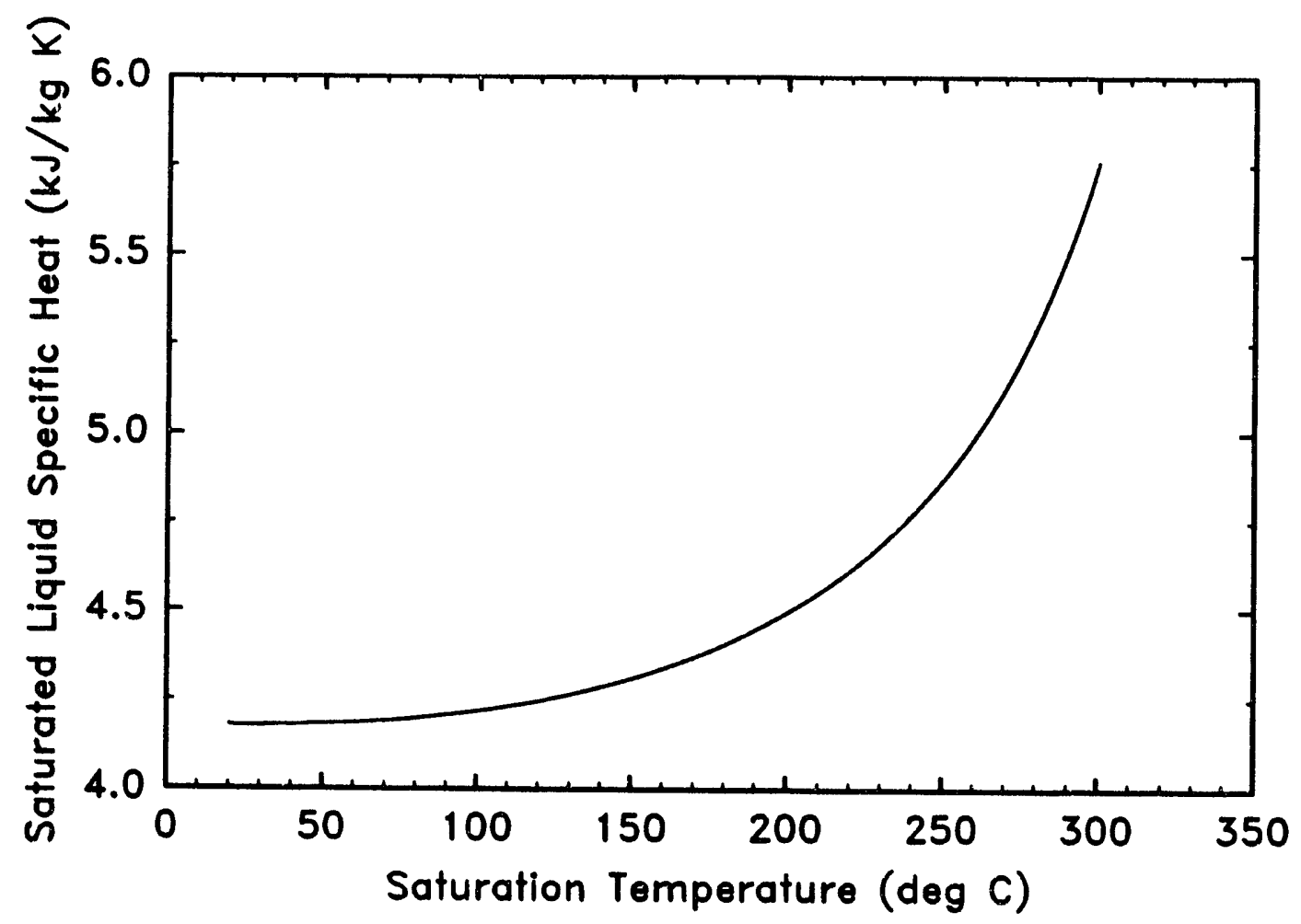

Fig. 9. $\mathrm{H}_{2} \mathrm{O}$ saturated liquid specific heat using Eq. 11 .

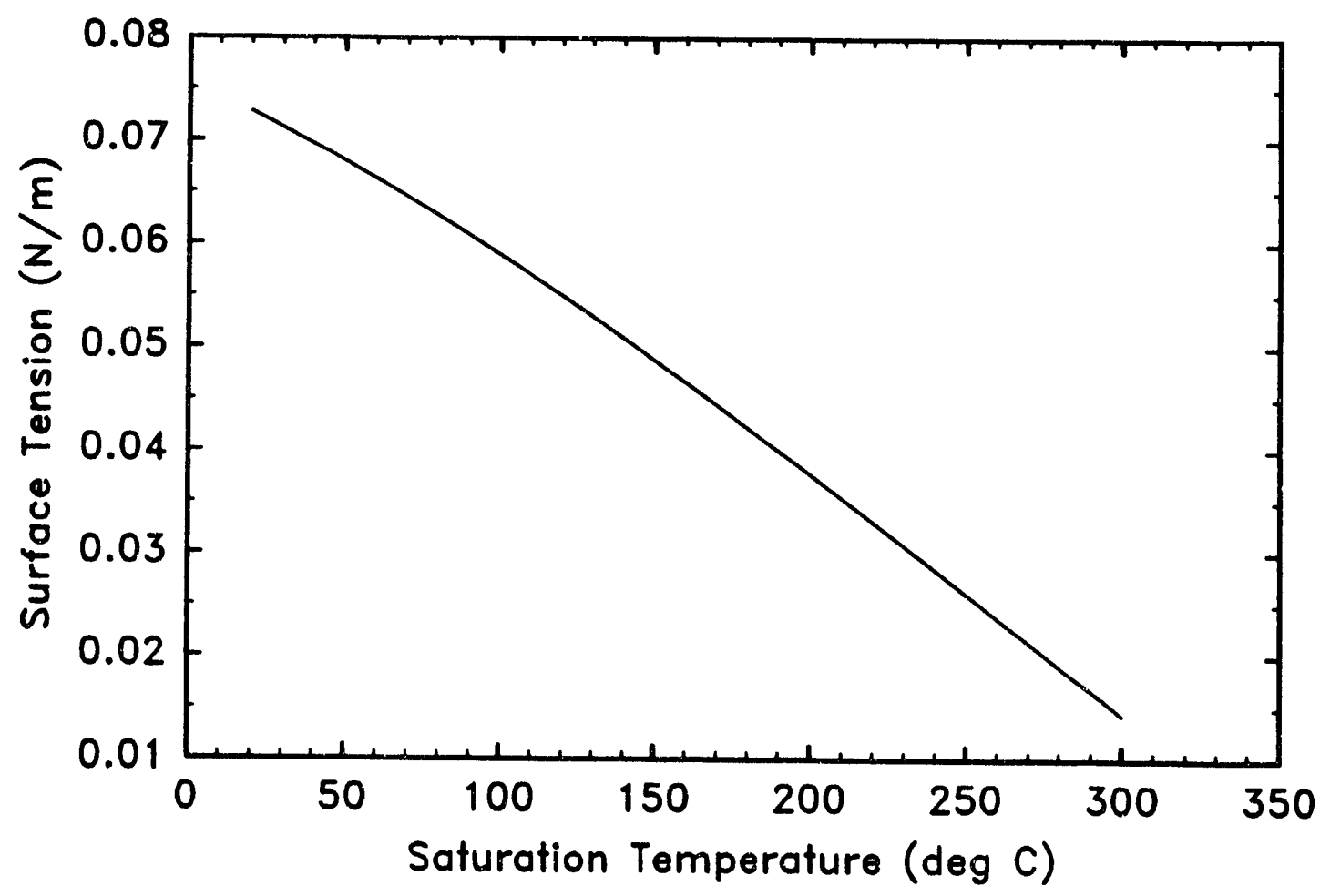

Fig. 10. $\mathrm{H}_{2} \mathrm{O}$ surface tension using Eq. 12 . 


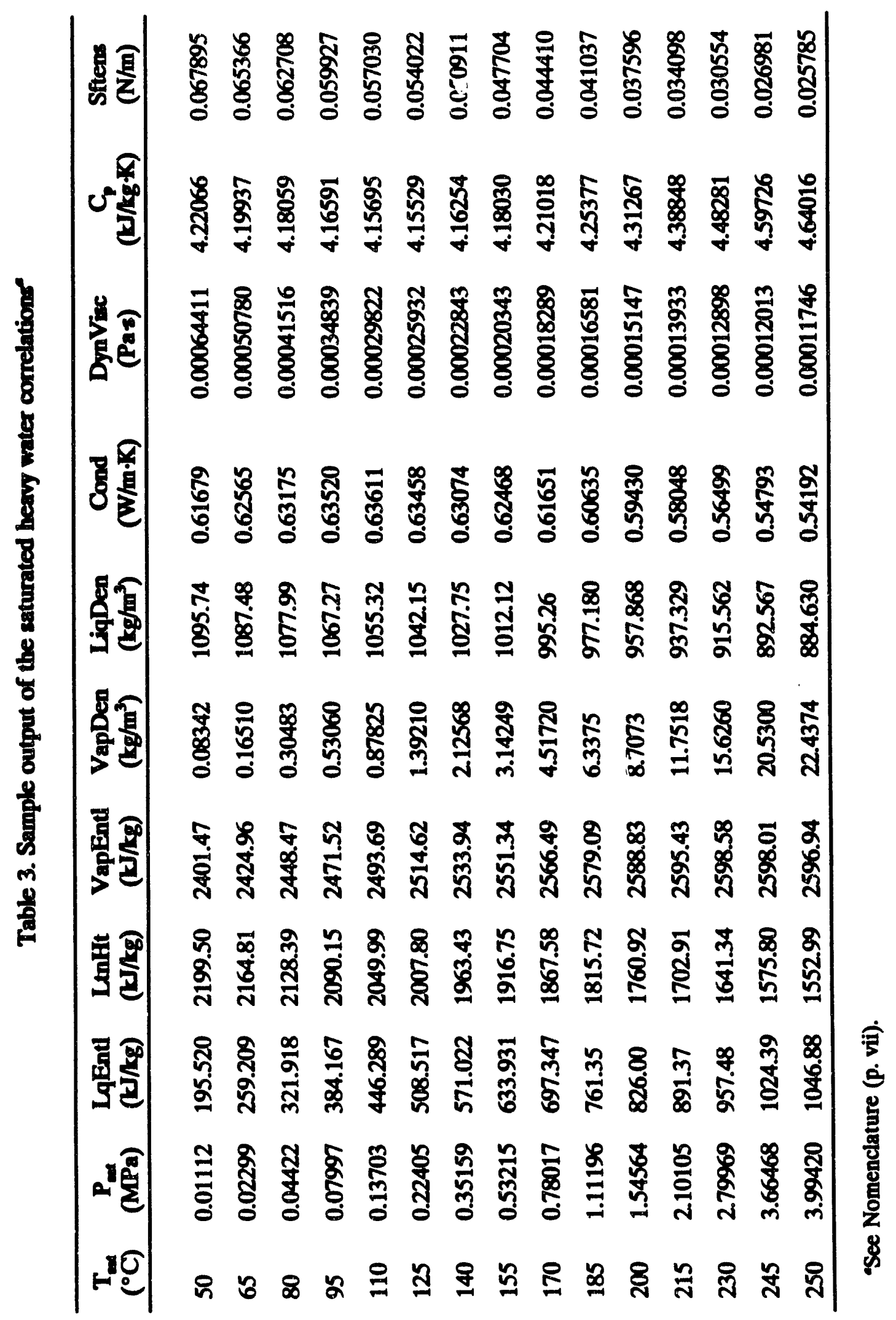




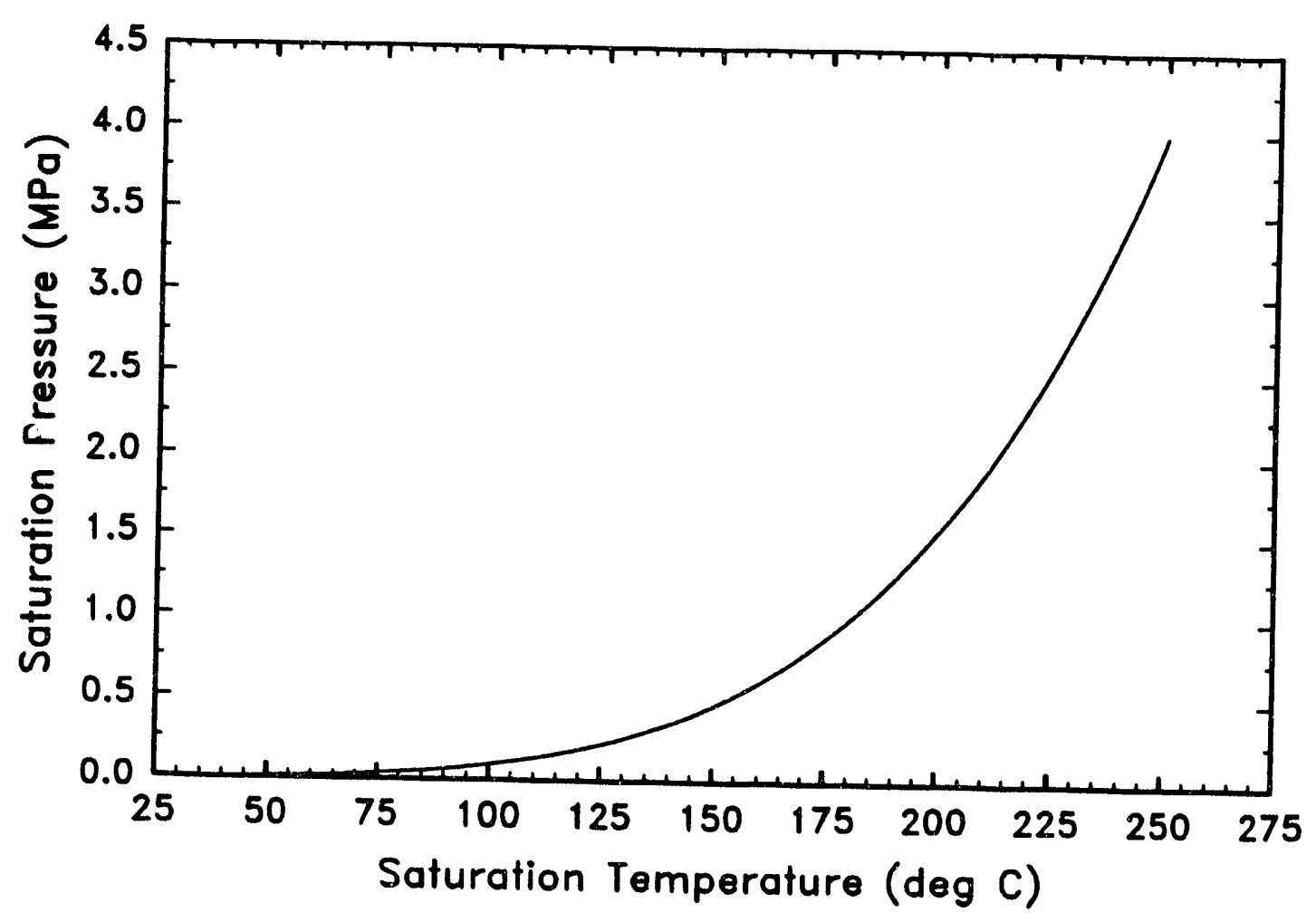

Fig. 11. $D_{2} \mathrm{O}$ saturation pressure using Eq. 15 .

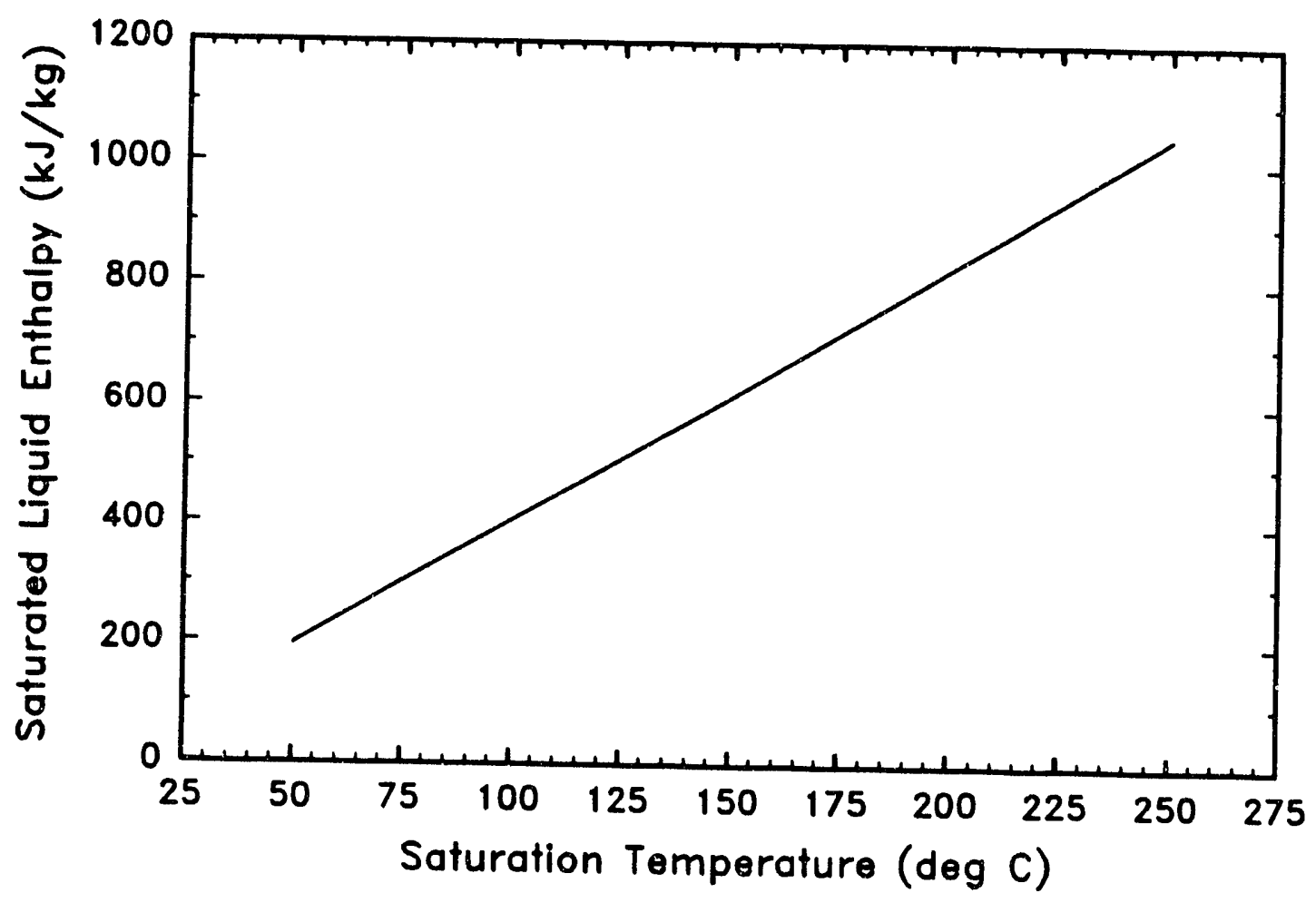

Fig. $12 \mathrm{D}_{2} \mathrm{O}$ saturated liquid enthalpy using Eq. 16. 


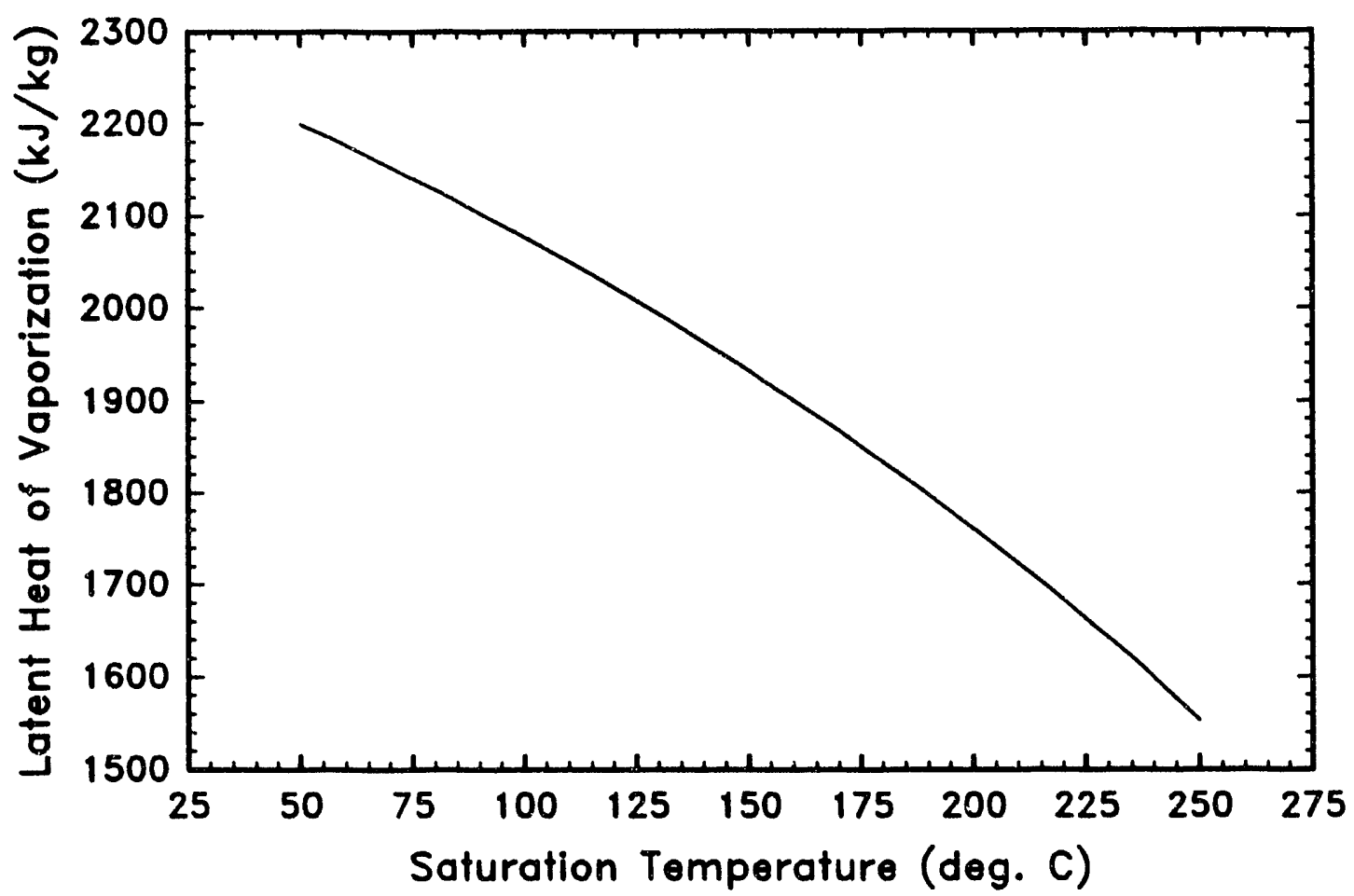

Fig. 13. $\mathrm{D}_{2} \mathrm{O}$ latent heat of vaporization using Eq. 17.

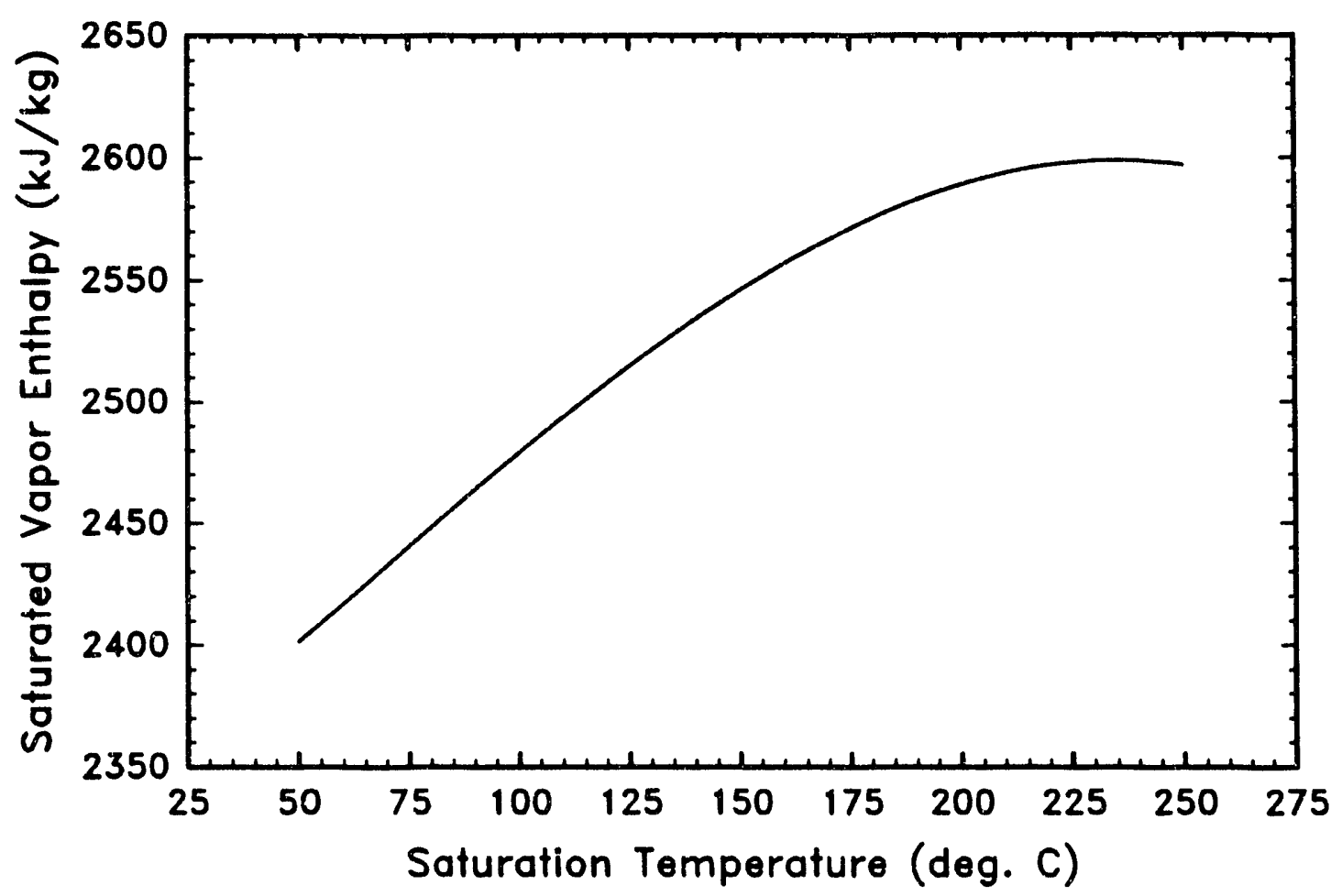

Fig. 14. $D_{2} O$ saturated vapor enthalpy using Eq. 18 


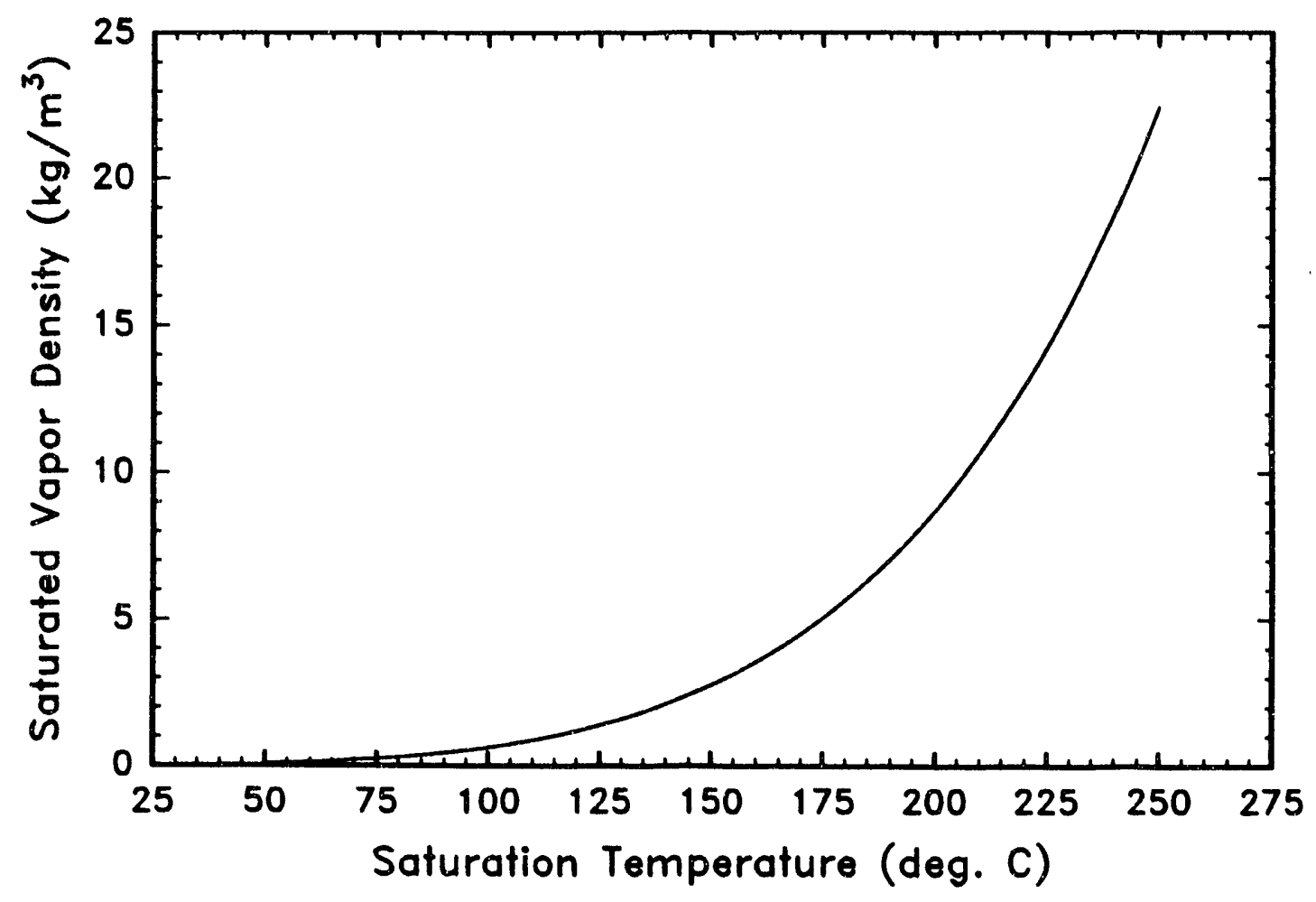

Fig. 15. $D_{2} \mathrm{O}$ saturated vapor density using Eq. 19.

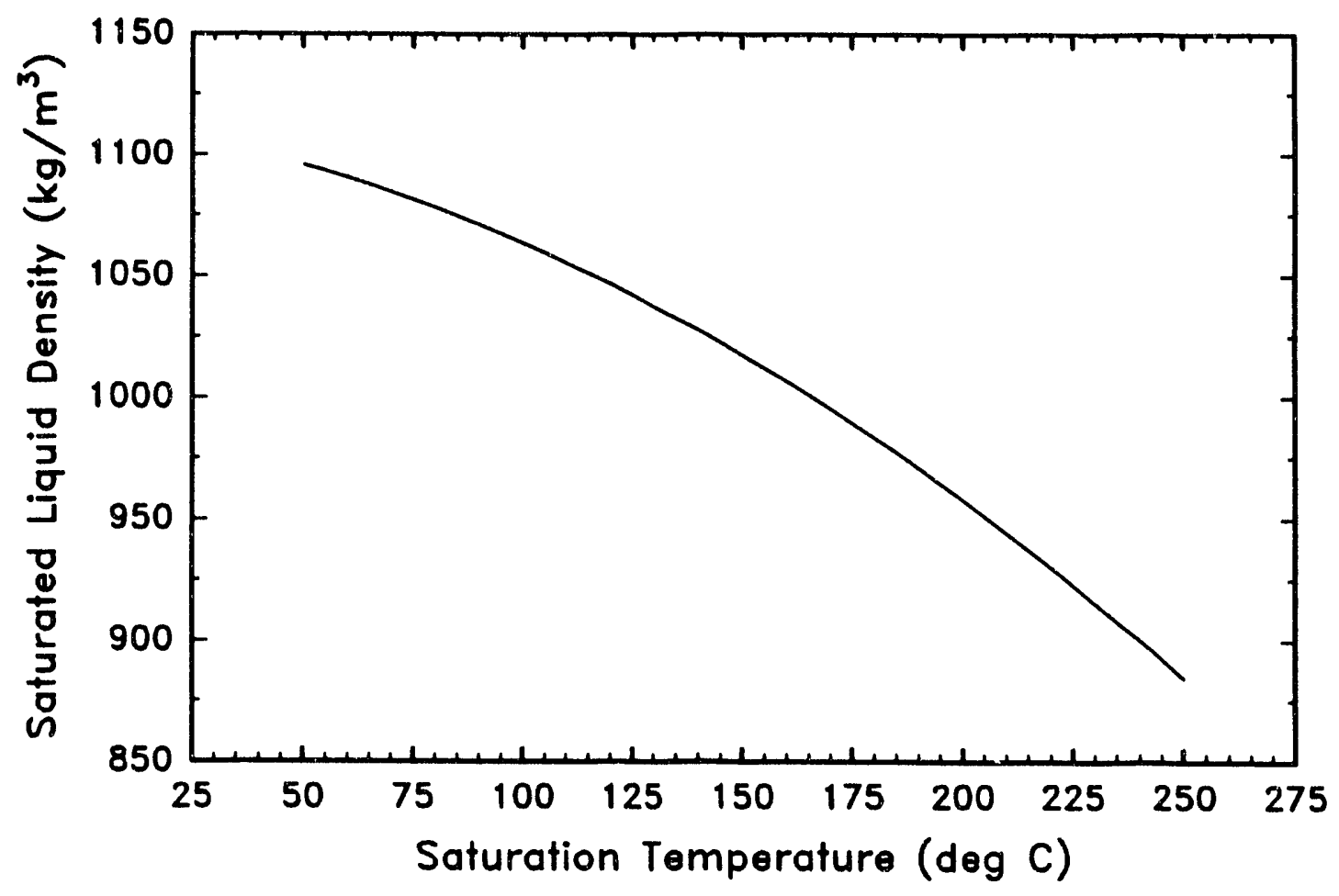

Fig. 16. $\mathrm{D}_{2} \mathrm{O}$ saturated liquid density using Eq. 20 . 


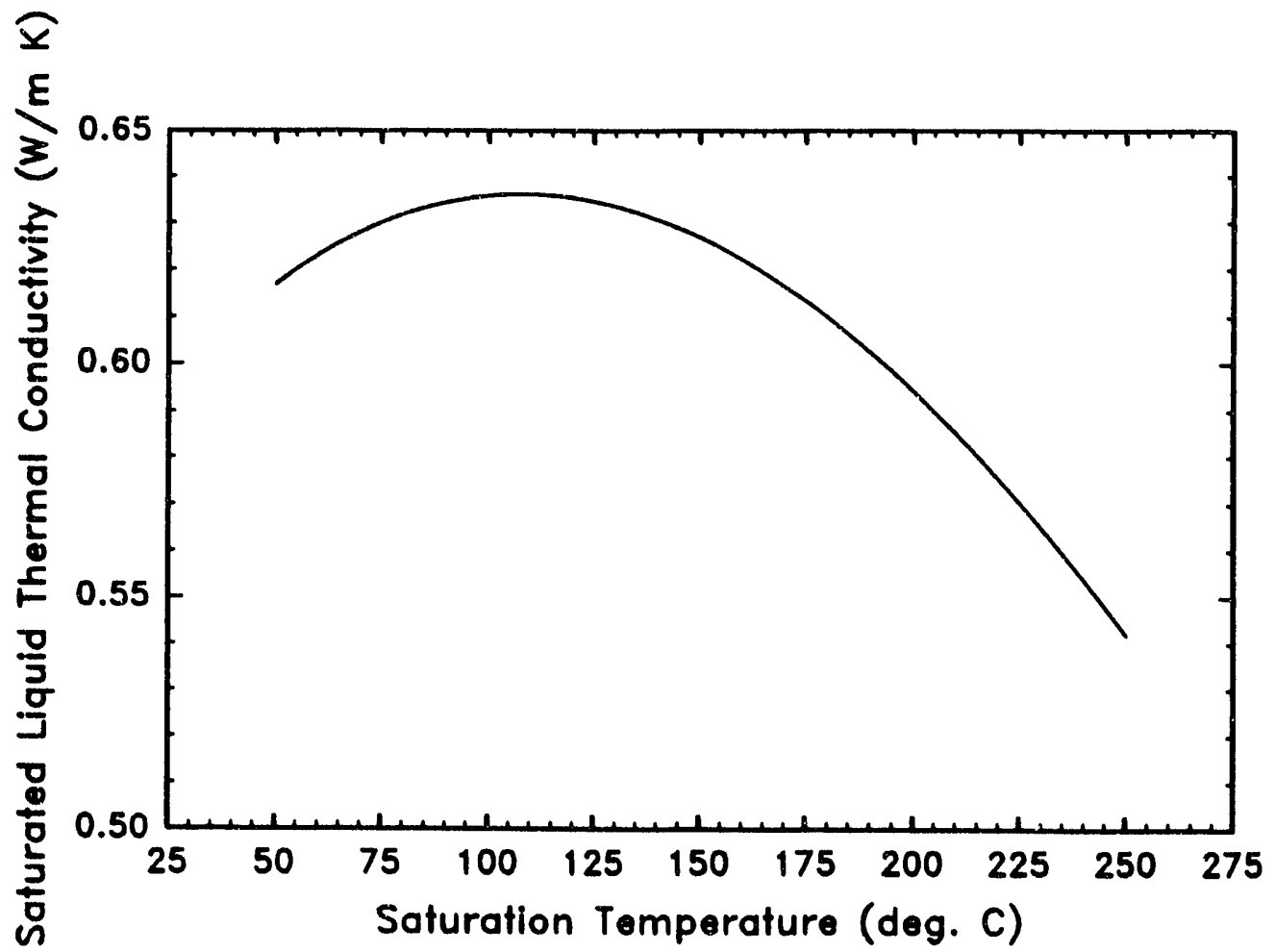

Fig. 17. $D_{2} \mathrm{O}$ saturated liquid thermal conductivity using Eq. 21.

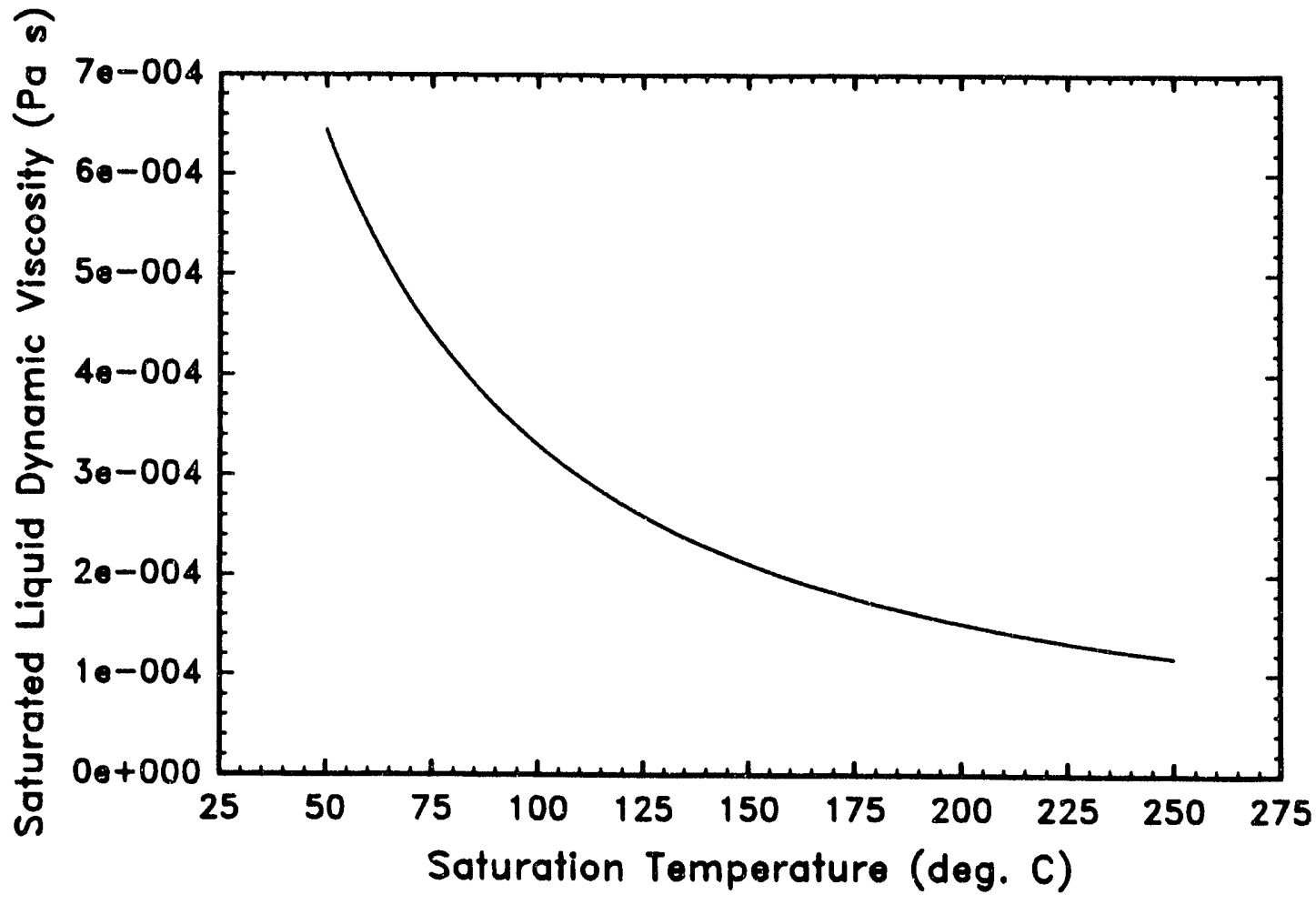

Fig. 18. $\mathrm{D}_{2} \mathrm{O}$ saturated liquid dynamic viscosity using Eq. 22 


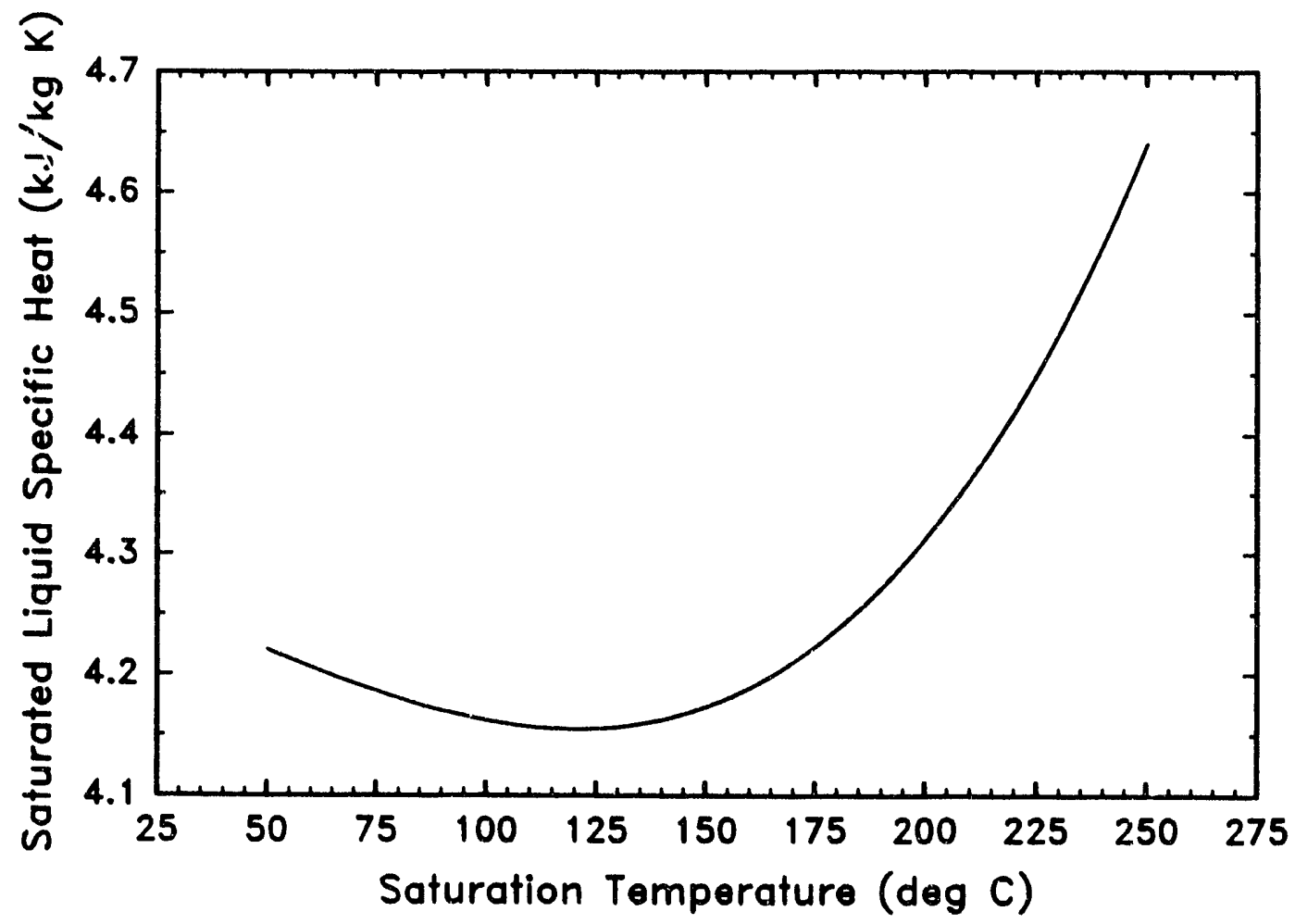

Fig. 19. $\mathrm{D}_{2} \mathrm{O}$ saturated liquid specific heat using Eq. 23.

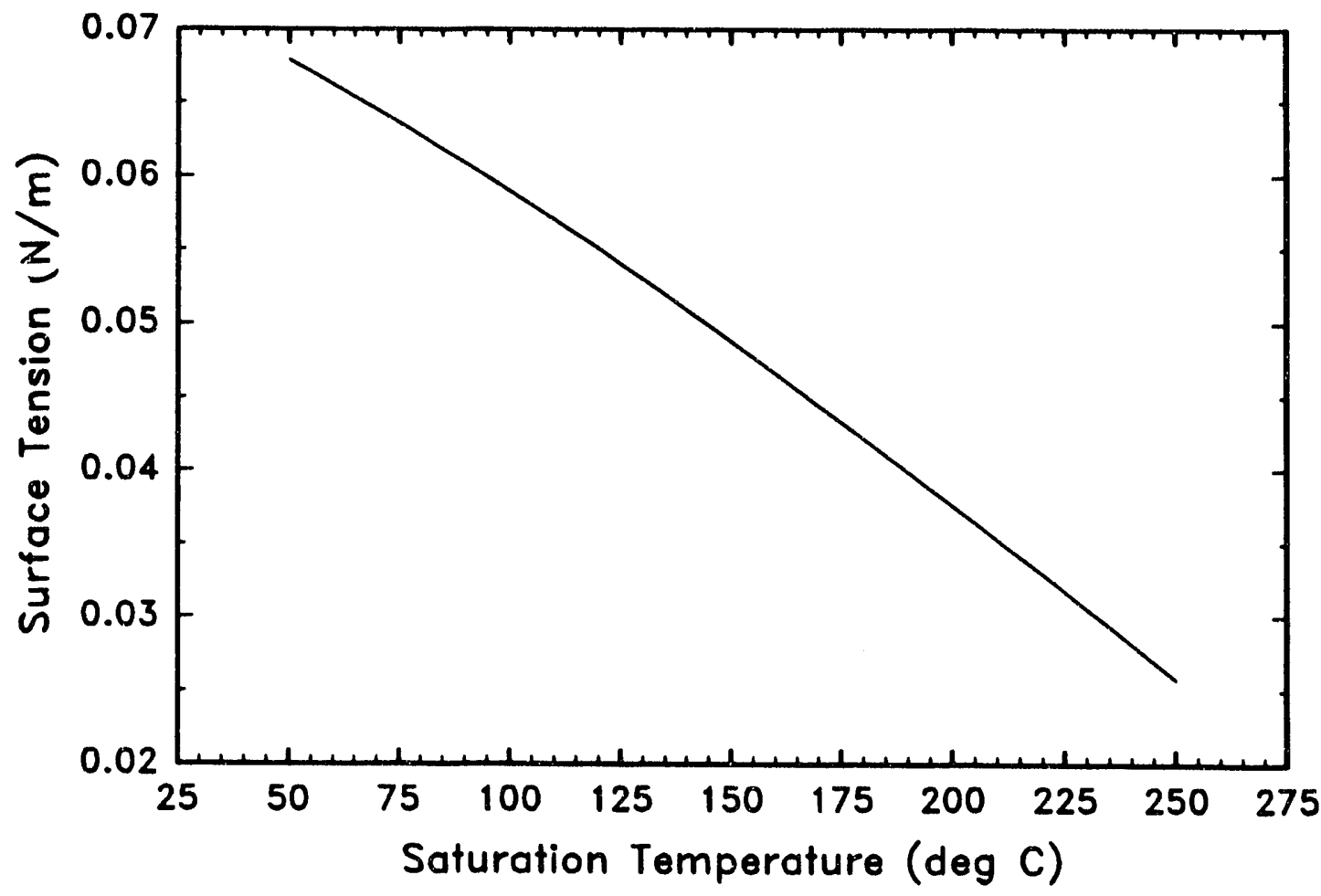

Fig. 20. $D_{2} O$ surface tension using Eq. 24 . 


\section{RECOMMENDATIONS}

The physical property correlations provided in this document are for saturated conditions only, but subcooled conditions will exist in the ANSR. Although subcooled conditions are nominal, local superheated conditions are also possible. As a result, the most prominent recommendation for future work is to determine the error associated with the use of these correlations in calculating properties at subcooled and superheated conditions. The error is not expected to be large since most of the physical properties do not have a strong dependance on pressure. If the resuling error is considered unacceptable, however, additional correlations will be necessary.

The correlation range was originally designed to cover ANSR nominal operating conditions. A need to broaden this range may arise as more safety analyses are performed. Many accident analyses, for example, would require correlation ranges comprising certain off-nominal operating conditions. It may be difficult, however, to maintain the same level of accuracy in a single correlation if the range is much broader.

It is encouraging to know that the interactive program, QuikProp, is actually being used and gaining popularity within the ANS project. As a result, it has been recommended that a Macintosh version of QuikProp be developed. Although the current version of QuikProp can run under Windows as a DOS application, a mouse-driven Windows version is desirable. 


\section{ACKNOWLEDGMENTS}

The authors would like to acknowledge the support of the ANS Project Office that made this work possible: the review of the original draft by J. C. Moyers, A. E. Ruggles, and R. D. Wichner; the review of the final draft by Norbert Chen and David Morris; and the guidance and review by Grady Yoder. The authors would also like to acknowledge the original contribution by T. Creek. 


\section{REFERENCES}

1. American Society of Mechanical Engineers, ASME Steam Tables, 5th Ed., 1983.

2. Joseph H. Keenan, Frederick G. Keyes, Philip G. Hill, and Joan G. Moore, Steam Tables, John Wiley and Sons, New York, N.Y., 1978.

3. P. G. Hill, R. D. MacMillan, and V. Lee, Tables of Thermodynamic Properties of Heavy Water in SI Units, AECL 7531, December 1981.

4. N. B. Vargaftik et al., "Table of Surface Tension of Heavy Water," in Water and Steam, Their Properties and Current Industrial Applications, Pergamon Press, 1980.

5. S. Kaizerman, E. Wacholder, and N. Tomerian, "A Thermophysical Heavy Water Properties Package for Thermal-Hydraulic Accident Analysis Codes," Nucl. Eng. Des. 80, 385-391 (1984).

6. Laurie Scott, Manager of Information Resources, Atomic Energy of Canada Limited, Canada, personal communication to J. A. Crabtree, Oak Ridge National Laboratory, Oak Ridge, Tenn., October 1992.

7. J. R. Heiks et al., "The Physical Properties of Heavy Water from Room Temperature to $250^{\circ} \mathrm{C}^{\prime \prime} \mathrm{HLM}-934$, January $12,1954$. 
Internal Distribution

1. C. W. Alexander

2. D. J. Alexander

3. R. R. Allen

4. E. E. Aluton

5. J. L. Anderson

6. B. R. Appleton

7. R. E. Battle

8. R. S. Booth

9. W. W. Bowman

10. R. A. Brown

11. G. J. Bunick

12. J. H. Campbell (5)

13. J. J. Carbajo

14. P. F. Cento

15. N. C. . Chen

16. K. W. Childs

17. K. K. Chipley

18. J. E. Cleaves

19. J. T. Cleveland

20. D. H. Cook

21. G. L. Copeland

22. B. L. Corbett

23-27. J. A. Crabtree

28. W. G. Craddick

29. J. S. Crowell

30. J. R. Dixon

31. H. L. Dodds

32. F. F. Dyer

33. Y. Elkassabgi

34. G. Farquharson

35. D. K. Felde

36. R. E. Fenstermaker

37. J. D. Freels

38. V. Georgevich

39. M. L. Gildner

40. G. E. Giles

41. H. A. Glovier

42. R. M. Harrington

43. J. B. Hayter

44. W. R. Hendrich

45. S. E. Holliman

46. M. M. Houser

47. M. Ibn-Khayat

48. D. T. Ingersoll

49-52. R. L. Johnson

53. J. E. Jones, Jr.
54. B. L. Lepard, Jr.

55. R. A. Lillie

56. P. S. Litherland

57. M. A. Linn

58. A. T. Lucas

59. J. A. March-Leuba

60. B. S. Maxon

61. G. T. Mays

62. M. T. M.Fis

63. S. V. M.

64. T. J. McNianamy

65. G. R. McNutt

66. J. T. Mihalczo

67. B. H. Montgomery

68. R. M. Moon

69. D. G. Morris

70. D. L. Moses

71. J. C. Moyers

72. W. R. Nelson

73. M. Olszewski

74. R. E. Pawel

75. H. R. Payne

76. F. J. Peretz

77. B. H. Power

78. C. C. Queen

79. S. Raman

80. C. T. Ramsey

81. J. S. Rayside

82. W. R. Reed

83. J. P. Rinier

84. J. B. Roberto

85. A. E. Ruggles

86. T. L. Ryan

87. D. L. Selby

88. H. B. Shapira

89. I. I. Siman-Tov

90-94. M. Siman-Tov

95. B. R. Smith

96. T. K. Stovall

97. W. F. Swinson

98. R. P. Taleyarkhan

99. L. H. Thacker

100. D. W. Thiesen

101. P. B. Thompson

102. K. R. Thoms

103. S. R. Tompkins 
104. B. D. Warnick

105. M. W. Wendel

106. C. D. West

107. J. L. Westbrook

108. R. B. Wichner

109. D. M. Williams

110. P. T. Williams

111. W. R. Williams

112. B. A. Worley
113. G. T. Yahr

114. G. L. Yoder

115. ORNL Patent Office

116-117. Central Research Library

118. Document Reference Section

119. Y-12 Technical Library

120-121. Laboratory Records Dept.

122. Laboratory Records, RC

\section{External Distribution}

123. R. Awan, U.S. Department of Energy, NE-473, Washington, DC 20585.

124. L. Y. Cheng, Brookhaven National Laboratory, Associated Universities, Inc., Bld !r. 120 Reactor Division, Upton, Long Island, NY 11973.

125. C. L. Christen, DRS/Hundley Kling Gmitter, 1055 Commerce Park Drive, Oak Ridge, TN 37830.

126-128. U.S. Department of Energy, ANS Project Office, Oak Ridge Field Office, FEDC, MS-821\%, P.O. Box 2009, Oak Ridge, TN 37831-8218.

129. C. D. Fletcher, Idaho National Engineering Laboratory, P.O. Box 1625, 2145 East 17th Street, Teton Village Complex, Idaho Falls, ID 83415-3885.

130. R. R. Fullwood, Brookhaven National Laboratory, Upton, NY 11973.

131. W. R. Gambill, Route 5, Box 220, Clinton, TN 37716.

132. B. Gupta, AECL Technologies, 1155 Metcalfe Street, 2nd Floor, Montreal, Quebec, Canada H3B 2V6.

133. A. F. Henry, Professor, Department of Nuclear Engineering, Massachusetts Institute of Technology, 77 Massachusetts Avenue, Cambridge, MA 02139.

134. R. A. Hunter, Director, Office of Facilities, Fuel Cycle, and Test Programs, Nuclear Energy Division, U.S. Department of Energy, NE-47, Washington, DC 20585.

135. L. C. Ianniello, Acting Associate Director, Office of Basic Energy Sciences, Office of Energy Research, U. S. Department of Energy, ER-10, Washington, DC 20585.

136. M. Kaminaga, Tokai Research Establishment, Japan Atomic Energy Research Institute, Todai-mura, Naka-gun, Ibaraki-ken, 319-11, JAPAN.

137. T. L. Kerlin, University of Tennessee, College of Engineering, 315 Pasqua Engineering Building, Knoxville, TN 37996-2300.

138. J. A. Lake, Manager, Nuclear Engineering and Reactor Design, Idaho National Engineering Laboratory, P. O. Box 1625, Idaho Falls, ID 83415.

139. J. E. Mays, Research and Test Reactor Fuel Elements, Babcock and Wilcox Co., P. O. Box 785, Lynchburg, VA 24505.

140-141. W. E. Meek, Project Manager, Gilbert/Commonwealth, Inc., P. O. Box 1498, Reading, PA 19603.

142. C. S. Miller, Idaho National Engineering Laboratory, P.O. Box 1625, Idaho Falls, ID 83415.

143. J. P. Mulkey, U.S. Department of Energy, NE-473, Washington, DC 20585.

144. C. H. Oh, Idaho National Engineering Laboratory, P.O. Box 1625, Idaho Falls, ID 83415. 
145. W. T. Oosterhuis, Materials Sciences Division, Office of Basic Energy Sciences, Office of Energy Research, U.S. Department of Energy, ER-132, Washington, DC 20585.

146. J. M. Ryskamp, Idaho National Engineering Laboratory, P. O. Box 1625, Idaho Falls, ID 83415-3885.

147. R. W. Shumway, Idaho National Engineering Laboratory, P.O. Box 1625, Idaho Falls, ID 83415.

148. J. L. Snelgrove, Coordinator, Engineering Applications, RERTR Program, Argonne National Laboratory, 9700 South Cass Avenue, Argonne, IL 60439.

149. P. I. Stumbo, Chief of Special Facilities Branch, Department of Energy, Oak Ridge Operations Office, P.O. Box 2001, Oak Ridge, TN 37831-2001.

150. I. Thomas, Director, Materials Science Division, Office of Energy Research, U.S. Department of Energy, ER-13, Washington, D.C. 20585.

151. J. M. Warren, Gilbert/Commonwealth, Inc., 1055 Commerce Park Drive, Suite 200, Oak Ridge, TN 37830.

152. P. W. Winkler, Air Products and Chemicals, Inc., 7201 Hamilton Boulevard, Allentown, PA 18195-1501.

153. H. G. Wood, III, Associate Professor, Department of Mechanical and Aerospace Engineering, Thornton Hall, University of Virginia, Charlottesville, VA 22901

154. Office of Assistant Manager for Energy Research and Development, DOE-Oak Ridge Field Office, P.O. Box 2001, Department of Energy, Oak Ridge, TN 37831-8600.

155-156. Office of Scientific and Technical Information, P.O. Box 62, Oak Ridge, TN 37831. 

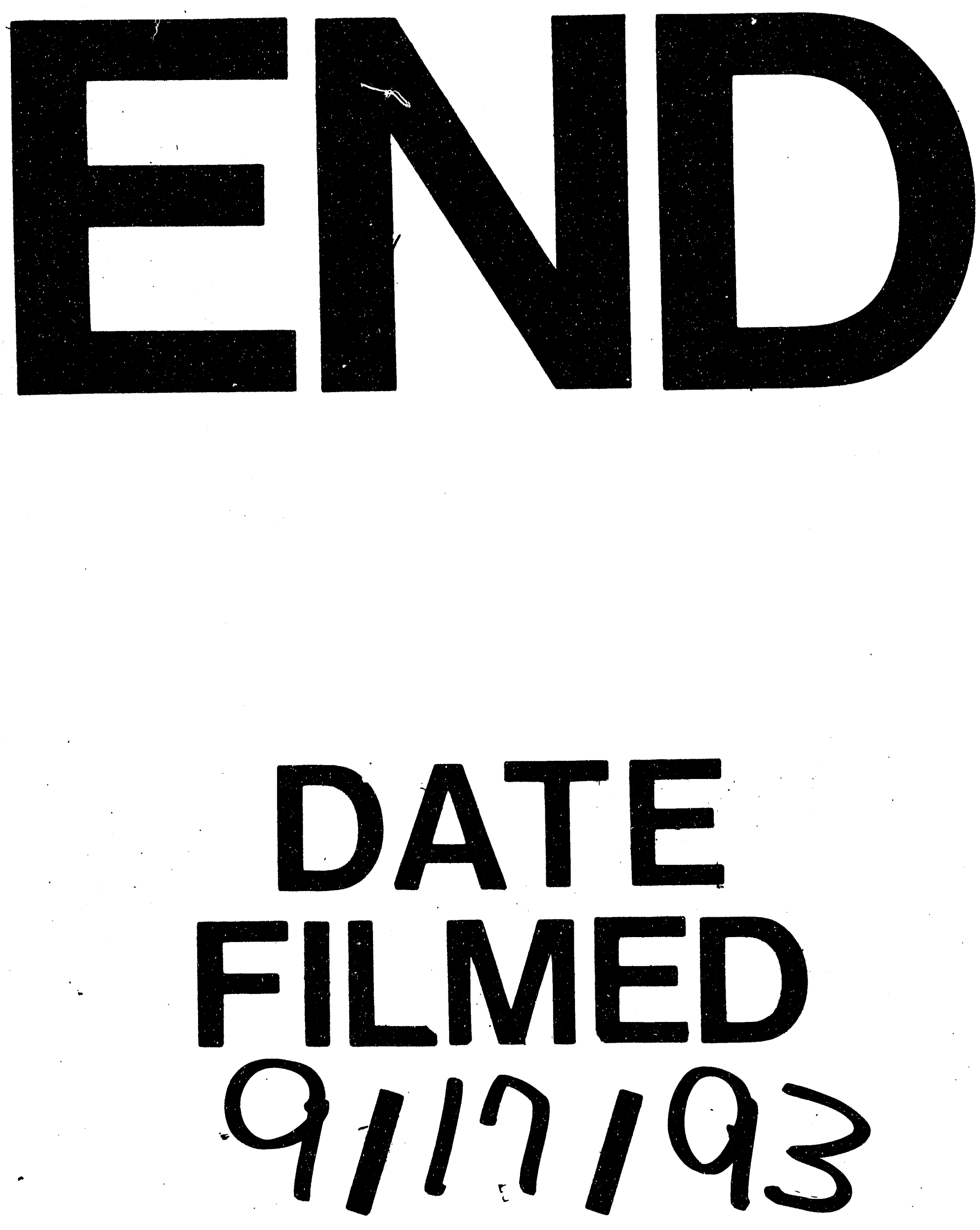

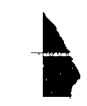


